\title{
A Apropriação das Tecnologias de Informação e Comunicação por Pessoas com Paralisia Cerebral
}

\author{
Ana Vilma Tijiboy * \\ Lucila Maria Costi Santarosa " \\ Liane Margarida Rockenbach Tarouco ".
}

\begin{abstract}
Resumo: $\mathrm{O}$ presentia arhgo apresenta os achatos de uma das questōes de pesquisa de urna tese de douterado que estudou a contribulçă das Tecrologias de Informaçro e Comunicactu e de ambientes computacionals de aprendizagem telematicos para o desenvolyiriento de pessoas com Paralisia Cerebral, desde a perspectlva dos Processos Psicológicos Superiores (PPS). Assim, săo discutidos aspectos teóricos importantes no que diz respeito às pessoas com Paralisia Cerebral e sua interaçăo com o mundo da forma como, geralmente, se evidencia na nossa sociedade. Propóeri-se conceitos diferentes

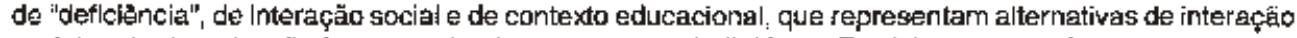
social mais rloa, desafiadora e motivadora para estes individuos. Explieita-se, termbem, o que a teoria Socio-historlca entende por desenvolvimento h umano, por processos psicolópicos superiores, e por uma intervençăo dentro da zona de desenwolvimento proxirnal, que busca etingir nowos estégios de aprendizagem e desserwolvimento o uma maior automia por parte de individucs "menos experientes", neste caso PNEEs. Em șeguida, apresentam-so os PPS evidenciados no estudo e as situaçōes en que foram observatos assim como temberm as definiçöes destes PPS. Finaliza-se por tecer algumas consideraçoses importantes.
\end{abstract}

Palawras-Chave: Paralis|a cerebral; Telemática; Educ日ẹăo especial; Informática né Educaçăo; Tơoria Sócio-histórica.

\begin{abstract}
This article presents the findings of one of the research questions of a doctoral thesis which studfed the contributions of the Infomm ition and Communication Technology and computer metwork lataming environments in the development of Palsied people, within the perspective of Higher Psychodogical Processes. Important theoretical aspents regarding the research subjects and their interaction with the world as it Is usually observed in our society are brought to disc ussion. Following, dlfferent concepts of "handicap". of social interaction and of educational context, are proposed. Such concepts represent altematives for $a$ social interaction, with more motiwating and stimulating situations for these individuals. The Social-historical theory understandings of human development, of higher psychological processes and of the pedagogical intervention within the proximal developmont zone, which aims to altain new stages of learning and development and a higher autonomy of the individduals is also preserted. Following, the Higher Psychological Pracesses observed in the study and tho situations in which they were delacted as wall as their defiritions are pressented. Finally, some important considerations are brought in.
\end{abstract}

Key-words: Cerebral Palsied; Telematics; Special Educatlon; Computers in Education; Sociat-Historical theory.

\section{Introdução}

O presente trabalho aborda algumas das contribuiçōes que as tecnologias de informaçāo e comunicaçāo, num ambiente de aprendizagem computacional telemático, têm aportado para o desenvolvimento de Peșsoas com Necessidades Educacionais Especiais. Concretamente, apresenta os resultados de uma des questóes de investigaçăo da tese de doutorado (Tijiboy, 2001) jurto ao Curso de Pós-Graduaçăo de Informática na Educaçăo, na Universidade Federal do Rio Grande do Sul.

Socióloga (UFRGS), Mestre em Educaçăo (Stanford University), Doutora gm Informática na Educaçăo (CCPG|EJUFRGS), membto da equipe de pesquisa a de atendimento no Núcleo de Informátice na Educagào Especial (NIEEUFRGS) e Professora do Curso de

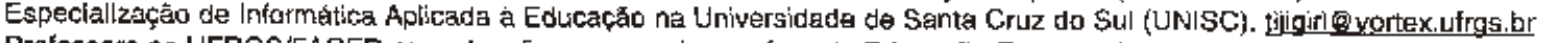

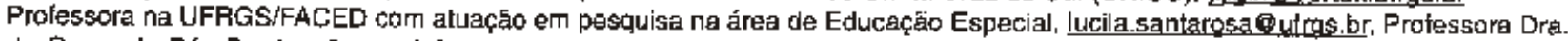

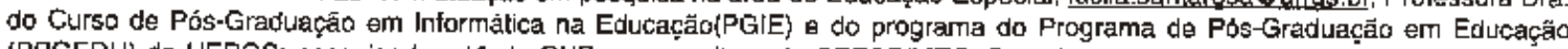
[PPGEDU) da UFRGS; pesquisadora IA do CNPq e consultora da SEESP/hEC; Precidente da Fedespecial-Brasil; coordenadora nacional ga RIBIE. Orientadora da Tese de Doutorado defendida em 2001 no PGiE.LFRGS

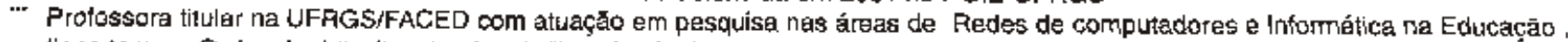

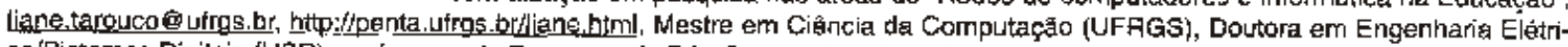
ca/Sistemas Digitais (LSP), profesera do Programa de Pós-Graduaça Informática na Educaçáa e do Programa de Pós-Graduaçăo enr Ciência da Computaçāo. Co-orientadora da Tese de Dótorado defendida em 2001 no PGiE-UFFGS 
A preocupaçāo que mobilizou a estudo foi a constalaçăo do contraste entre duas realidades tāo próximas e, ao mesmo tempo, tăo distanciadas. De um lado, os avanços tecnológicos (TICs) cada vez mais acelerados e poderosos na expansăo sem fronteiras da comınicaçăo e do desbravamento do espaço; de outro, seres hujmanos excluídos do convivio social, em funçăo de severas limitaçōes precisamente de comuricaçāo e mobilizaçāo no espaço. Aproximar estas duas realidades e estudar que ganhos as pessoas com Paralisia Cerebral podem obter quando interagern com esta tecnologia foi o objetivo principal do estudo.

Corvém ressahtar que ernbora outros trabalhos envolvendo ambientes de aprendizagerm telemáticos e pessoas com Paralisia Corebral tivessem já sido desenvolvidos em centros de pesquisa nacionais e no próprio NIEE, a originalidade do estudo, aqui apresentado, consistiu em examinar a contribuiçăo de tais ambientes sob uma ótica diferente. Isto é, o referencial teórico utilizado, proveniente preponderantemente da teoria Sóciohistórica, permitiu examinar o desenvolvimento de pessoas com Paralisia Cerebral (enquanto se apropriavam dos recursos do ambiente computacional telemático criado) referindo-se especificamente aos Processos Psicológicos Superiores (PPS) ou funçōes mentais superiores evidenciados no processo de apropriação.

A coleta direta de dados durou dois anos e meio e foi realizada no Núcleo de Informática na Educação (NIEE) da Universidade Federal do Rio Grande do Sul (UFRGS), onde os sujeitos de pesquisa interagiram com as TICs. As unidades de análise foram dois sujeitos com Paralisia Cerebral do tipo espástica paraplégica moderada (caso 1 do estudo) e espástica tetraplégica severa (caso 2), ambos com 20 anos de idade no inficio do estudo. A metodologia utitizada foi de natureza qualitativa, mais especificamente constituindo-se em dois estudos de caso, em que se fez uso das estratégias metodológicas de "imersăo" e "mergulho" na busca de pistas e evidèncias para a compreensão do fenômeno em estudo.

\section{O que é Paralisia Cerebral}

A fim de compreender o que significa Paralisia Cerebral e que implicações traz para as pessoas que a apresentam, alguns pontos importantes săo aqui abordados. O termo Paralisia Cerebral é utilizado no geral, de uma forma ampla e engloba distúrbios diversos, porém, que têm em comum uma alteração ou perda de controle motor de movimento e de coordenação, devido a uma lesão encéfálica, ocorrida na etapa pré-natal, durante o parto ou no periodo da primeira infância. Encontram-se assim incluidas desde perturbaçōes motoras leves, até alteraçöes que impossibilitam a realizaçăo de, praticamente qualquer movimento voluntário. Outros distúrbios senşoriais como o da visăo e da audiçăo podem estar associados em diversos niveis e säo considerados desde o nommal ou o superior até a deficiência grave, isso em relaçāo á dimensão cognitiva. A epilepsia também pode estar presente e costuma ocasionar quedas freqüentes, o que torna necessário um tratamento com uso de medicamentos. Devido à perturbaçăo nos músculos bucofonatórios, evidencia-se, em alguns casos, salivação sem controle, fazendo com que a pessoa babe. A lesão é irreversivel, no entanto, as faculdades de substituiçäo e de compensação dos centros cerebrais năo lesionados sâo muito importantes, podendo conseguir-se grandes resultados quanto mais precoce for a intervençăo de profissionais de diversas áreas, relacionadas à comunicação e ao controle postural, entre outros.

A literatura esclarece que o termo Paralisia Cerebral diferentemente do que parece sugerir, não é propriamente uma paralisia, nem é cerebral, no sentido que nāo se trata de paralișia do cérebro ou de qualquer outra parte do corpo. Contrariamente ao que o termo pode sugerir, o cérebro dessas pessoas nunca deixa de funcionar (Souza, 1998). A Paralisia Cerebral consiste em "um distúrbio motor complexo que pode incluir aumento ou diminuiçąo do tónus em determinados grupos musculares, alteraçöes da postura ou equilibrio, e/ou da coordenaçāo e precișăo dos movimentos" (Basil, 1995, p. 254). Assim, apesar da existēncia de distúrbios relacionados à disfunçăo motora, o intelecto e muitas das funçöes regidas pelo cerebro freqüentemente não são afetadas.

No Brasil, năo existem estatisticas muito precisas, nem muito atuais, quanto ao número total de casos de Paralisia Cerebral na populaçăo, mas para se ter uma idéa, segundo Andrade (2001), no Brasil situam-se, a cada ano, entre 30.000 a 40.000 recém-nascidos com diagnóstico de Paralisia Cerebral.

Quanto à classificação das Paralisias Cerebrais, esta pode ser com base nos efeitos funcionais, na topogratia corporal $\theta$ ainda no grał do comprometimento. Raras vezes, porém, estas tipologias são apresentadas de forma pura, sendo que o mais comum săo os casos mistos. Com base nos efeitos funcionais, os quadros clínicos encontrados com maior freqüencia sáo a espasticidade, a atetose e a ataxia. Existerm ainda a rigidez ou tremores, mas săo menos freqüentes. Com base na topografia corporal, os tipos podem ser: paraplegia, tetraplegia, monoplegia, diplegia, triplegia e hemiplegia (Andrade, 2001, Besil, 1995, Souza e Ferraretto, 1998 
e Torres e Carmona, 1999). Com base no grau de comprometimento motor, as paralisias cerebrais podern ser leves, moderadas e severas (Valente, 1983).

A paralisia do tipo espástica, presente em ambos os sujeitos do estudo, caracteriza-se por apresentar um aumento acentuado do tônus muscular. Verifica-se um excesso de contrações musculares as quais podem ser do tipo que ccorre em repouso ou do tipo de contração que acontece ou se acentua com o esforço ou em decorrancia de emoçóes. Isso ocorre em situaçöes em que a pessoa se assusta por alguma mudança em seu meio ambiente, ou pela dificuldade que apresenta frente a alguma pergunta dirigida a ela. As características de postura da espasticidade săo; - extensāo e aduçăo predominante nos membros anteriores, - hipertonia, geralmente, manifestada nos flexores dos membros superiores; existe tima rotaçāo interna nos braços, o cotovelo está semiflexionado, o polegar unido à palma da mắo e os dedos e p pulso flexionados. A alteração da expressảo facial é de forma tal que a linguagem oral é disarticulada ou até inexiste. A paralisia paraplégica, presente no sujeito do caso 1 do estudo, implica o comprometimento das duas pernas. A paralisia tetraplegica, presente no caso 2 do estudo, por sua vez envolve tanto os membros superiores quanto os inferiores (Basil, 1995).

A paralisia moderada, presente no caso 1 , afeta a motricidade total e fina, enquanto que a paralisia severa, presente no caso 2, implica inabilidade por parte da pessoa em realizar atividades do dia-a-clia como, por exemplo, carninhar, se vestir, se alimentar e realizar a higiene pessoal (Valente, 1993).

\section{A Interação com o Mundo das Pessoas com Paralisia Cerebral}

Enfocando a interação das pessoas com Paralisia Cerebral com seu contexto, os aspectos sócioculturais adquirem uma conotaçăo especial a ser considerada. Devido a um conjunto de fatores que interferem severamente na sua interaçāo com o mundo, tais como $D$ aspecto físico "desagradável", a dificuldade de comunicaçảo e as limitaçōes motoras, esses indivíduos são vistos pela sociedade como incapazes, "disabiles", "inaptos", "menos válidos", "débais mentais", "deficientes", entre outros termos. A desinformação e o preconceito são, em grande parte, responsaveis por serem essas pessoas vistas como tristes e patéticas, incapazes de se desenvolverem além da fase infantil, dependentes durante toda a sua vida, e por isso excluidas e alienadas do processo produtivo. Elas são ainda vistas como doentes que precisarm de cuidados médicos e incapazes de compreenderem a realidade que as cerca, sendo às vezes até sugerida uma vișāo de predestinaçāo (Figueira, 1995). Tal percepção social tende a perpetuar a relação dessas pessoas com a sociedade, como uma interação desestimulante e pouco desafiadora, no seu processo de desenvolvimento. Consonante com essa percepçăo de incapacidade, o que se espera desses individuos, tanto no ambiente educacional como em outros ambientes, é pouco e, portanto, o que se oferece a eles também é pouco.

Além da percepção social negativa, tais pessoas vivenciam uma pealidade particular desde o inicio da vida, uma vez que se leva em consideraçăo que tanto a capacidade de comunicação como a de mobilidade independente são elementos fundamentais para o desenvolvimento humano. Neste sentido, o que as pessoas com Paralisia Cerebral experimentam tende a comprometer seu deservolvimento cognitivo e social. Con sua mobilidade prejudicada, as oportunidades para brincar e explorar săo reduzidas, o que, apesar de suas inúmeras tentativas, as levam a experimentar a sensação real de pouco controle sobre o mundo, uma vez que os canais preponderantes de interação se constituem na fala e no movimento independente. Assim, é de se supor que tal interaçāo social, caracterizada por obstáculos e privaçzes constantes, acarreta atraso no desenvolvimento desses individuos que acumulam, ao longo da vida, sentimentos de frustraçāo, desmotivaçăo e confiança reduzidas. Todos estes fatores acabam, por sua vez, diminuindo ainda mais as oportunidades de exploraçāo do mundo, já bastante restritas, desde as etapas iniciais da infảncia. Esse processo se torna um ciclo destrutivo de privaçóes que häo contribui para o seu desenvolvimento humano, a partir de, segundo Nisbet et al. (1996), uma perspectiva holística.

A qualidade e a quantidade de interação socialsão, sem dúvida, ingredientes poderosos para o desenvolvimento emocional e cognitivo. O compartilhar, com os outros, interesses, experiencias, dúvidas, pensamentos e sentimentos é que caracteriza a interação social, sendo este tipo de comunicaçăo entre as pessoas da mesma cultura aquilo que as une. O que ocorre com pessoas cuja comunicaçaáo está comprometida pela impossibilidade deste compartilhar com os outros, è o fato de que estăo marginalizadas da sua própria cultura (Michalaros, 1998). Mais preocupante ainda è a constataçăo de que, muitas vezes, até mesmo esforços bem intencionados, que visam desenvolver o potencial das PNEEs, erroneamente, insistam em trabalhar unicamente no nivel concreto, por acreditarem que essas pessoas são capazes apenas deste tipo de raciocínio (Wygotksy, 2000). Convencidos disto, utilizam, predominantemente, métodos do imitaçāo, exercício, repetiçäo e treina- 
mento, que acaba tendo um resultado contrário ao desejado, ao negar a essas pessoas a oportunidade de acesso ao nivel mais evoluido do desenvolvimento humano - o pensamento abstrato.

\section{Um Conceito Alternativo de "Deficiéncia", de Interaçăo Soclal $\theta$ de Contexto Educacional}

Nestes ültimos anos, contrapondo-se ao preconceito social e mais especificamente à abordagem de "disabiles", emerge um conceito alternativo de indivíduos "divers-abiles", isto é, indivíduos capazes, mas de forma diferente (Ghezzo, 1999). Emerge ainda a conotação "dEFICIENTE" (minuscula na primeira letra da palavra, mudando completamente o sentido), cujo uso vem crescendo entre as próprias pessoas com necessidades especiais, refletíndo uma implicita auto-imagem de competência, tal como a imbutida no próprio termo e que contesta a concepção preconceituosa e dominante em nossa sociedade (Andrade, 2001).

Entende-se assim que o desafio do momento, na educação especial, consiste, justamente, numa abordagem do tipo "divers-abiles" e na construçáo de um ambiente educacional ennquecedor. Tal perspectiva supera a exclusão social tradicional, com relaçăo a pessoas com Paralisia Cerebral ou outra necessidade especial, percebendo-as como pessoas capazes, ao mesmo tempo que enfatiza suas potencialidades, ao invés de suas limitaçōes. Posșibilitar que as Pessoas com Necessidades Educacionais Especiais usufruarn da multiplicidade de novas oportunidades que as tecnologias de informaçâo e comunicaçăo oferecem atualmente - passando a ter uma interaçắ de maior e melhor qualidade com o mundo - é contribuir para que ampliem sua participaçäo social, como sujeitos com uma nova condiçăo de cidadania.

Dentro desse novo horizonte educacional, os ambientes de aprendizagem alternativos, ao invés de reproduzirem seres humanos passivos e meros receptores de informaçỏes, devem procurar contribuir comn a formaçäo de sujeitos ativos, questionadores, criativose construtores de conhecimento. Em outras palavras, é urgente que tais ambientes desenvolvam o potencial educacional e social dos envolvidos - uma decorrência crucial dessa concepçăo.

Lembrando que, em grande parte, săo as vivências sociais pobres, no que diz respeito a recursos e situaçōes geralmente oferecidas às Pessoas com Necessidades Educacionais Especiais, o que atrasa sua aprendizagem e desenvolvimento, é de fundamental importância que os ambientes de aprendizagem alternativos estejam impregnados de expectativas positivas quanto a esses individuos. E preciso também que lhes sejam proporcionadas situaçōes significativas, interessantes e desafiadoras que estimulem a exploraçăo, as descobertas, a testagem de hipóteses e a construçào de conceitos.

Os esforços educacionais, em geral, e também os específicos com Pessoas com Necessidades Educacionais Especiais, devem aspirar por novos estágios evolutivos e nảo pela estagnação em estagios do desenvolvimento ja ałcançados. Criar, portanto, ambientes que propiciem atividades que visern o desenvolvimento do pensamento abstrato e avançar nessa direçăo. Ambientes de aprendizagem computacionais podem significar propostas promissoras nesse sentido.

Os educadores que interagem com PNEEs ' , por sua vez, devem ser incentivadores da aprendizagem, suficientemente sensiveis e preparados para trabalharem dentro da zona de desenvolvimento proximal de cada um. Essa abordagem inplica, portanto, em uma constante regulaçăo do tipo de intervençăo rumo a uma mediaçăo cada vez mais sútil, menos diretiva, no sentido de estimular a reflexāo e a construção do conheçimento pelo próprio sujeito. As atividades propostas devem vir ao encontro das necessidades dos alunos, abrangendo aspectos não apenas cognitivos, mas sociais e afetivos.

Outra caracteristica desses ambientes deve ser a de que o aluno esteja em posiçăo de comando do instrumental e năo na situação inversa, o que contribui para o senso de autonomia e responsabilidade perante sua própria aprendizagem. Em tais ambientes o errar tem um caráter natural inerente ao processo de aprendizagem e de construção, o que acaba incentivando investidas ousadas, sem o temor ou o receio de serem os individuos rotulados de incapazes, caso suas tentativas nảo sejam exitosas. Devem ser previstas, tambem, situaçốes de aprendizagem em ambientes cooperativos, por propiciarem a reflexão e a descentraçăo do seu próprio pensar, a partir de diversos pontos de vista, além de desenvolverem atitudes cooperativas, as quais são aspectos fundamentais, que humanizam as pessoas nesta época digital em que vivemos.

Estes ambientes devem propiciar o acesso a um maior número de recursos tecnológicos de informaçăo e de comunicaçąo, visando a uma expansăo do mundo para os indivíduos em questāo, até hoje consistentemente limitado, tanto em funçăa de suas reais dificuldades motoras $\ominus$ de comunicação, como também devido 
à percepçāo que a sociedade mantém sobre eles. É importante também proporcionar um tipo de interaçăo social mais positiva estimulante, em que se acredite no potencial das Pessoas com Necessidades Educacionais Especiais, desafiando-as a explorarem novos caminhos, a fazerem novas descobertas a se instrumentalizarem melhor nesta era techológica, visando assim uma participação de cidadania mais ativa. Desse modo, o ambiente educacional deve oferecer recursos e situaçós que revelem e desenvolvam o potencial desses indivíduos, ao invés de enfatizarem a "deficiência" ou a necessidade especial, como sinônimo de déficit intelectual. Foram estas proposiçōes que nortearam a construçąo do ambiente de aprendizagem computacional telemáticos do estudo.

\section{A Teoria Sócio-hiștóriça: uma teorla sobre o degenvolvímento humano}

Uma vez que pretendia-se estudar de que forma as tecnologias de intormaçąo e comunicação podiam contribuir no desenvolvimento de pessoas com Paralisia Cerebral, procurou-se uma teoria que pudesse auxiliar a compreender este fenómeno. Optou-se, assim, pela teoria Sócio-histórica por vir ao encontro de várias das nossas convicçōes. Uma das principais premissas dessa teoria, por exemplo, é que os seres humanos săo produtos, näo somente da Biologia mas também de suas culturas. O funcionamento intelectualé desse modo, - produto de nossa histónia social, e a linguagem è o meio através do qual aprendemos nossas culturas, organizamos nosso pensamento verbal e regulamos nossas ações (Tinzmann et al., 1990).

A interaçăo social tem, nesto perspectiva teórica, importância fundamenial no desenvolvimento da cognição. Nesse sentido, as crianças aprendem as funçōes mais altas, interagindo ativamente com adultos e com outras crianças ao seu redor. Dixon-Krauss (1996) afima que, para Vygotsky, o desenvolvimento cognitivo se deve às interaçōes sociais desses indivíduos com seu meio, bem como pela idéia da atividade socialmente significativa que encontra sua explicaçāo na consciência. Para Vygotsky (1984), os mecanismos da conduta humana e os mecanismos da consciència são os mesmos; o individuo tem consciência de si mesmo, porque está ciente da existência de outros.

As teses centrais da teoria Sócio-histórica se referem ao caráter histórico e sociał dos processos psicológicos superiores, e ao papel que os instrumentos de mediaçāo têm nesses processos. Mais explicitamente, elas afirmam que: (a) os processos psicológicos superiores (PPS) têm uma origem histórica e social e que (b) os instrumentos de mediaça (ferramentas e signos) cumprem urn papel central nesses processos superiores (Baquero, 1998). O estudo das funçôes psicologicas superiores, processos mentais superiores, ou processos psicologicos superiores, foram o foco principal de Vygotsky $(1984,1987)$, uma vez que o referido autor pretendia compreender os mecanismos psicológicos mais sofisticados, mais complexos, tipicos do ser humano.

Varios aspectos relevantes dessa teoria, que contribuem para a compreensáo do fenômeno estudado no que se refere ao processo de apropriação das novas tecnologias de informaçăo e comunicação, por parte de pessoas com Paralisia Cerebral, säo apresentados no trabatho original (tese de doutorado). Contudo, aqui, por razóes de espaço, nos limitaremos apenas aos Processos Psicológicos Superiores e à Zona de Desenvolvimento Proximal e ao suporte nesta zona. O primeiro (PPS) por ser o objeto de estudo eo segundo (ZDP) por constituir-se em elemento fundamental de intervençäo da pesquisadora junto aos sujeitos de pesquisa.

\subsection{O Desenvolvimento Humano e os Processos Psicalógicos Superiores (PPS)}

Para Vygotsky (2000) o desenvolvimento é um processo dialètico complexo que se caracteriza por periodicidade; irregularidade no desenvolvimento das diferentes funções; metamoffose ou transformaçăo quahitativa de uma forma em outra; inter-relaçäo de tatores internos e externos; e processos adaptativos que superam e vencem os obstáculos com os quais a criança se depara. Conforme Berg (1970, apud Vygotsky, 2000 , p. 1B5):

"O desenvolvimento mental da criança é um processo contínwo de aquisiça de controle ativo sobre fumções mentais inicialmente passivas. Para obter tal controle, a criança aprende a utilizar os signos para transformar estes funçōes mentais "naturais" en tunçōes culturais envolvendio signos".

Vygotsky (2000) também distingue, dentro de um processo geral de desenvolvimento, duas linhas, as quais considera qualitativamente distinfas e de origem diferente, referindo-se aos processos elementares e as funçōes psicologicas superiores. Os primeiros șáo de origem biológica e os segundos de oŕgem sociocultural. O mesmo autor afirma ainda que "a conduta da criança nasce a partir da interrelaçăo dessas duas linhas" (Vygotsky, 2000, p. 79). 
Descrever e especificar o desenvolvimento daquelas tomas de inteligéncia especificamente humanas, fọi uma das preocupaçóes principais da tecria Sócio-histórica (Wygotsky, 1984, 2000). Wertsch (1995) lembra, por sua vez, que diferenciar as funçóes psicológicas superiores e elementares tém uma longe tradição na Pṣicologia; a distinçāo básica surge da necessidade de separar os tenómenos psicológicos comuns a animais e humanos daqueles que são especificamente humanos. Basicamente, os processos psicológicos superores representam um nivel qualifativamente superior, de funcionamento psicologico. Dessa foma, bimpossivel explicar os processos superiores a partir dos princípios explicativos que regem as funçóes elemerttares.

Os processos psicol6gicos elementares existem tanto em homens como em animais, mas os processos psicológicos superiores säo especificos dos seres humanos. Nas palauras de Vygotsky (1984, p. 53),

"As funçöes elementares têm como característica fundamental o fato de serem total a diretamente determinadas pela estimulaçåo ambiental. No caso das funçōes superiores, a caracteristica essencial á a estimulaçáo autogerada, isto é, a criaçăo o o uso de estimulos artificiais que se tomam a causa imediata do comportamenta".

Tanto o processo de internalizaçăo como a utilização de sistemas simbólicos são essenciais para o desenvolvimento dos processos psicológicos superiores, Um e outro evidenciam a importāncia das relaçöes sociais entre os individuos, na construçäo dos processos psicológicos.

\section{Com base em, Vygotsky, Oriveira (1997, p. 42) define os processos psicológicos superiores como sendo}

".aqueles que caracterizam of funcionamento psicológico tipicamente humano: aços conscientemente controladas, atençäo voluntá ria, memorização ativa, pensamento abstrato, comportamento intencional. Os Processos Psicológicos Superiores se diferenciam de mecanisnos mais alementares, como refiexos, reaçós aLtomaticas, associaçōes simples".

Essa diferenciaçāo é essencial para a compreensão do funcionamento humano. Para Baquero (1998) os processos psicológicos superiores (PPS) se originam na vida social e implicam a particjpação do sujeito em atividades compartilhadas com outros. Tais processos sao especificamente humanos, enquanto histórica $\theta$ socialmente conştituídos e pressupōem a exiśténcia dos processos elementares nåo sendo estes, porém, condição suficiente para sua apariçăo, isto é, os processos superiores săo muito mais complexos, näo sendo, portanto, estado avançado dos processos elementares.

Mecanismos biológicos como a linha de desenvolvimento natural regulam os processos psicológicos elementares (PPE) , estando muitos deles presentes em outras espécies, além do hornem. Memorizaçáo, atividade de senso-perceptivo e motivaçào, entre outros, sāo exemplos desses PPE. Mais ainda, Baquero (1998) salienta que, mesmo que possa haver uma certa automaçăo posterior, os processos psicológicos são regulados conscientemente (ou o foram em algum momento) e se valem do uso de instrumentos de mediaçáo, sendo que a forma de maior relevância é a mediaçáo semiótica.

Os processos psicologicos elementares, que săo básicos para toda a aquisição futura de processos superiores, nâo desaparecem, mas se reorganizam e, em alguns casos, se transformam. Assim, a constituiçăo dos processos superiores nazo ocorre como continuaçäo da linha natural de desenvolvimento nem è um progresso dos processos elementares. Sua corstituliçäo na vida social implica que os próprios mecanismos formadores, em boa medida, estejam organizados na vida social. O sujeito é, portanto, um resultado da relaça ativa dele com as coisas no seu meio e com as outras pessoas. Nesse sentido, "as funçōes superiores näo säo apenas um requisito da comunicação, mas o resuttado da própria comunjaçăo" (Rivière, 198B, p. 41-42, apud Baquero, 1998).

Referindo-se a urt processo psicológico especifico - a memória - V/vgotsky (1984, p. 52) compara a versăo sccial, mediada (o que a constitui em um processo psicologico superior) com a sua versăo naturat, não mediada (processo psicológico elementar). Nessa comparaçá, o autor deixa transparecer, de forma geral, os traços que caracterizart as funçōes psicológicas superiores:

i... mesmo nos estágios mais primitivos do desenvolwimento social, existem tipos fundamentalmente díferentes de memória. Uma delas, dominante no comportamento de povos iletrados, caracteriza-se pela impreşão neio mediada de materlajs, pela retençăo das experiéncias reais como a base dos traços mrnemónicos (de memória). Nós a chamamos de memória natural... Esse tipo de memoria está muito próxima da percepçăo, uma vez que surge como consequência da inflǘncia direta dos estimulos externos sobre os seres humahos. Do ponto de vista da estrutura, o processo todo caracteriza-se pela qua-. lidade de imediatismo." 
No entanto, mesmo no caso de homens e mulheres iletrados, a memória natural năo é o único tipo encontrado. Coexistem com ela outros tipos de memória, provenientes de linhas de desenvolvimento completamente diferentes. Por exemplo, o uso de pedaços de madeira entalhada, de uma escrita primitiva e de auxílios mnemônicos simples são evidências de que os seres humanos, mesmo em estágios mais primitivos do seu desenvolvimento histórico, traspassaram os limites das funções psicológicas impostas pela natureza. Esta superação de limites naturais representa uma evoluçăo de seu comportamento, constituindo-se em uma organização nova elaborada culturalmente.

Mesmo operações relativamente simples, como a incorporação de auxiliares mnemônicos, modificam a estrutura psicológica do processo de memoria. A operação de memória é, através de tais operaçóes, estendida para além das dimensões biológicas do sisterna nervoso humano, originando umá forma inteiramente nova de comportarnento (Vygotsky, 1984).

Com base no trecho acima, Wertsch (1995), percebe quatro critérios principais nos processos psicologicos superiores: (1) emergência da regulação voluntária, passando o controle do ambiente para o individuo; (2) o surgimento da realizaçáo consciente dos processos psicológicos; (3) as origens sociais e a natureza social das funçöes psicológicas superiores e (4) o uso de signos como mediadores das funçöes psicológicas superiores.

"A primeira característica que diferencia os processos psicológicos elementares dos superiores, é que os primeiros astăo sujeitos ao controle do contorno, do ambiente, enquanto que os superiores săo autoregulados" pelos própríos indivíduos (Wertsch, 1995, p. 43). Isso acontece através da criaçāo de estímulos artificiais, isto é, da estimulaçăo auto-gerada, que é sua primeira caracteristica. Nessas condiçōes, as funçōes psicológicas superiores são mais complexas "genética e funcionalmentente" (Nygotsky 1960, apud Wertsch, 1995, p. 43).

A segunda caracteristica dos processos psicológicos superiores é que estes sāo "intelectualizados", ou seja, sāo realizados conscientemente. Vygotsky (1934a, apud Wertsch, 1995) afirma que as funçöes psicológicas superiores tẻm como caracteristicas básicas a intelectualização e o domínio, isto é, a realização consciente e a voluntariedade.

Portanto, dominar uma hunção é alcançar um grau de intelectualizaçäo. A memória se intelectualiza na escola equivale a dizer que a memória voluntária aparece. Da mesma forma, dizer que a atenção se torna voluntária, no periodo escolar, equivale a dizer que cada vez mais esta funçäo se fundamenta no intelecto.

A origem social é a terceira característica das funçỏes psicológicas superiores. Para Wygotsky, segundo Wertch (1995): "năo é a natureza, mas a sociedacte que deve ser considerada como o fator determinante do comportamento humano". Nesse sentido. Vygotsky analisava a transiç̧ăo no indivfduo a partir da influência social externa para uma influência social interna colocando-a como foco de seus estudos. A quarta característica, $\dot{a}$ a mediaçāo que significa que

"o controle voluntário, a realizaça consciente a natureza social dos processos psicológicos superiores pressupōem a existencia de ferramentas psicológicas ou signos, que poderm ser utilizados para controlar a atiwidade do próprio sujeito e das denais pessoas" (Wertsch, 1995, p. 44).

Com relação aos processos psicológicos superiores, Wertsch (1995, p. 44) salienta que "...o controle voluntário, a realização consciente, as origens sociais e a mediaçăo, através do uso de ferramentas psicológicas, caracterizam o funcionamento intelectual na teoria de Vygotsky". Ao contrário, as funçōes psicologicas elementares se fundamentam no controle do ambiente sabre elas. O seu caráter não é consciente, suas origens são individuais e estas nāo envolvem um processo de mediaçāo através de ferramentas psicológicas.

Com relaçăo aos PPS, Vygotsky (1984, apud Baquero, 1998) faz uma divisão entre PPS Rudimentares e PPS Avançados. Esta distinçăo é complexa e importante. Na primeira subcategoria - os PPS Rudimentares ficariam incluidos os que parecem possuir certo atributo de universalidade. A linguagem oral estaria aqui incluída, pois sua aquisiçăa se produz por meio da intemalização de atividades socialmente organizadas. A segunda subcategoria - os PPS Avançados - se caracteriza por um maior uso de instrumentos de mediação, com crescente independéncia do contex to e de regulaçăo voluntária e realizaçāo consciente. A linguagem escrita se situaria aqui, pois requer uma ruptura com o contexto imediato e um maior controle consciente e voluntário do que a linguagem oral. Assim, os PPS Avançados nạo se produziriam dentro de processos de socialização genéricos, como acontece no caso da fala, mas seriam adquiridos através de processos instituidos de "socializaçăo" especificos, como o processo de escolarização. 
Segundo Wertsch (1995), ambas linhas de desenvolvimento - natural e cultural - coincidem e se confudem entre si, penetrando uma na outra, formando assim basicamente uma única linha de formaçāo sócio-biológica. Sua fusta, num processo urificado, não deveria ser compreendida como aditiva, mas como co-formante dos processos psicologicos. Nesse contexto, vale ainda considerar a citação que Baquero (199g, pag 224) traz de Van der Veer e Valsiner:

\footnotetext{
i. as pessoas näo apenas possuen ferramentas mentais, elas também săo possufdas por elas. Os melos culturais - a fala em particular - näo săo extermos às nossas mentes, mas crescem dentro deles. criando, desse modo, uma segunda natureza. $\mathrm{O}$ que Lurie e Vygotsky pensavam $b$ que o domínio dos meios culturais transformaria nossas mentes: uma criança que dominou a ferramenta cultural da linguagem nunca será a mesma criança..."
}

Luria (1990), ao estudar individuos provenientes de contextos socio-culturais diferentes, constatou que estes apresentam tipos diversos de pensamento predominantes (situacional/concreto/prático x categorial/abstratof que săo decorrentes dos contextos sócio-culturais, aos quais eles pertencem. Mais especificamente, o mesmo autor constatou, nos diversos grupos, a exiştência ou năo de funçóes psicologicas superiores que considera serem as mais importantes, ou seja, a percepçäo, a generalizaçăo e a abstraçăo, a dedução e a inferéncia, o raciocínio e a soluçāo de problemas, a imaginaçăo, a auto-anălise e a auto-Gonsciencia.

Em suma, com base nas consideraçoses da literatura até aqui discutidas, talvez se pudesse dizer que toda operaçäo mental que os indivíduos realizam sob re o mundo, fazendo relaçöes, planejando, comparando, lembrando, sem a presença real de objetos ou pessoas, recriando e reintemretando informaçōes, conceitos e significados também estão inciluídos dentro da całegoria de PPS.

\subsection{A Zona de Desenvolvimento Proximal (ZDP) e o suporte neste zona}

Nas palavras de Vygotsky (1997, p. 89) "a discrepancia entre a idade mental real de uma criança e o nivel que ela atinge ao resolver problemas com o auxílio de outra pessca indicam a zona do seu desenvolvimento proximal". Similarmente, a instrução precede e lidera o desenvolvimento, ou seja,

"o que uma criança pode fazer hoje em cooperaçāo, será capaz de fažer sozinha amanhă. Fortanto o único tipo positivo de aprendizagern é aquele que caminha à frente do desenvolvimento, servindo-Ihe de guia; deve voltar-se nāo tanto para as furç̧̄es já maduras, mas principalmente para as funçōes em amadurecimento" (Wygotsky, 1987, p. 89).

O mesmo autor acredita que uma boa instrução deve focalizar os niveis superiores da zona de desenvolvimento proximal do aprendiz, o que implica que uma criança deve engajar-se em atividade instrucional que é, na realidade atual, muito difícil para ela realizar independentemente, devendo seu desempenho ter o apoio de alguém mais capaz. Este apoio se de através do dialogo social. A zona de desenvolvirnento proximal, continua o mesmo autor, "defire aquelas funçōes que ainda näo amadureceram, mas que estäo em processo de maturaçāo, funçōes que amadurecerăo, mas que estāo presentemente em estado embrionário." (Wygotsky, 1984, P. 97).

A instruçăo dentro da zona de desenwolvimento proximal começa com a ideja vygotskiana de que o caminho para aprender é o da interaçăo social ao funcionamento independente internalizado (Wygotsky, 1984 ). É uma progressāo contínua que, inicialmente, é regulado pelo outro, rumo a un desempenho auto-regulado. Mais recentemente, alguns pesquisadores ocidentais têm avançado nas investigaçóes sobre o conceito da zona de desenvolvimento proximal. Nesse sentido, Dixon-Krauss (1996) afima que Wertsch tem focalizado seus estudos no diálogo entre adulto e criança e que Cole, por sua vez, tem estudado esse papel dentro desta zona de desenvolvimento proximal, constatando que o papel do professor envolve 3 elementos-chave. Estes seriam, entāo, (a) que o professor media ou aumenta a aprendizagem da criança através da interação social conforme um e outro văo construindo cooperativamente pontes de consciência, entendimento e competência; (b) que o papel de mediaçáo do professor é flexivel; o que ele faz ou diz depende dos elementos que a criança fornece enquanto engajados na atividade; (c) o professor focaliza sua atençăo na dimensảo de apoio necessário que pode variar desde direçōes muito explicitas até dicas vagas.

Vygotsky enfatiza que a instruçăo escolar fornece o contexto social e cultural para desenvolver as funçōes mentais superiores das crianças (Vygotsky, 1984). É interessante observar que a autohomia no desenvolvimento se obtem de uma forma paradoxal, como produto de assistência ou auxilio, o que forma uma relação dinâmica entre aprendizagem e desenvolvimento (Vygosky, 2000). Nesse sentido, a aprendizagem năo equivale a desenvolvimento, porém ela, uma vez organizada, se toma desenvolvimento mental e pōe em mar- 
cha uma serie de processos evolutivos, que jamais poderiam ocorrer sem a aprendizagem. A aprendizagem é. pois, urn aspecto universal a necessário do processo de desenvolvimento culturalmente organizado e especifico das funçōes psicológicas do ser humano.

Portanto, o suporte proposto pela teoria Sócio-histórico, consiste em uma situaçåo de interaçāo entre um sujeito especializado ou mais experimentado num domínio e outro novato, ou menos especializado, sendo que a interaçăo objetiva que o sujeito menos especializado se aproprie gradualmente do saber especializado. O novato deve participar, desde o início, numa tarefa reconhecidamente complexa, mesmo que sua participaçăo ínicial seja sobre aspectos parciais da ațvidade global e mesmo quando se necessite do "suporte" do sujeito mais especializado para poder resolver seu probiema (Tinzmann et al., 1990). Inicialmente, talvez o sujeito mais experiente tenha um controle maior da atividade, mas passaria a delegá-la gradualmente ao novato. Tal procedimento implica uma desmontagem progressiva. Este suporte deve, entāo, ser ajustảvel, conforme o nivel de competéncia do menos experiente e seus progressos com o tempo, mas que näo seja crônico pois isto năo proporciona autonomia. Foi este o tipo de suporte propiciado aos sujeitos deste estudo.

\section{Os Resultados: Processos Pslcologicos Superiores e outros processos de desenvolvimento}

As pistas de desenvolvimento coletadas na fase de imersăo do estudo, apontaram vảrios indicadores. Desses, selecionou-se aqueles considerados principais, ou seja, os seguintes processos psicológicos superiores (PPS) ou funçöes mentais superiores: linguagem falada social, linguagem escrita social, linguagem escrita, linguagem falada egocêntrica, atenção, merrória, solução de problemas, imaginação, auto-rêflexão/auto-consciẹncia, inferência/dedup̧ão. Todos esses são PPS e se encontram na literatura referente à teoria sócio-histórica. No entanto, também foram detectados outros processos de desenvolvimento que, embora năo constem na literatura de estudos sob a teoria Sócio-histórica, por estarem muito presente ao longo do processo de apropriação por serem considerados importantes, também foram levados em conta. Estes foram: auto-estima/ autoconfiança, postura cooperativa e capacidade de sintese.

Cabe esclarecer que os indicadores referentes ao desenvolvimento apesar de haverem surgido da observaçāo direta na fase de imersăo, chegaram a sua versāo final após serem confrontados com a teoria. Estes se constituiram em instrumentos de observação na fase de confirmação dos dadọ coletados, isto é, na fase de mergulho. Tais indicadores são apresentados no quadro 1 (ver página seguinte).

Com base nas definições presentes no quadro 1, apresentamos, a seguir, os processos de desenvolvimento e as situacōes em que estes foram evidenciados enquanto os sujeitos de pesquisa interagiam com as TICs, isto é, enquanto se apropriavam dos recursos do ambiente de aprendizagem computacional telemático criado.

\section{Linguagem Falada Social}

No caso 1, esta linguagem constatou-se em inúmeras situaçöes do processo de apropriaçăo. O sujeito 1 a utilizou para sugerir e propor formas de trabalho, para solicitar ajuda, convidar colegas a jogarem listas criadas por ele ou para convence-los, por exemplo, de que era ele quem deveria ficar no controle direto do equipamento, argumentando que, dessa foma, o trabalho em grupo seria mais rápido e eficaz.

Atravès da linguagern falada social o sujeito 1 (S1) solicitava e emitia opiniōes, manifestava dúvidas e perguntava sobre a forma correta de escrever diferentes palavras. Via este PPS, o sujeito 1 questionava o funcionamento dos diversos software com que trabalhava, manifestava desejos ou curiosidades, compartilhava descobertas. Em alguns casos, tambem pedia explicaçá a pesquisadora sobre qual tinha sido seu raciocínio para a soluçáo de determinado problemá, tendo, nestas ocasiôes, a linguagem falada a funçāo de auxiliar na verificação da lógica de seu raciocínio e detectar o "erro" cometido.

A linguagem falada social esteve presente em situaçōes em que o sujeito dava instruçóes sobre como proceder a colegas menos experientes: "Aqui (mostrando a tela) aparece como se fosse uma folha em branco"; "Vai em ferramentas, o menu, depois em opfóes geral para tu colocar teus dados" (explicando como a pessoa devia proceder para configurar seu perfil de usuário no Netmeeting). Explicou sobre o funcionamento de recursos de comunição síncrona "A flor verde você está online e se passar um e-mail eles respondem. A flor vermetha está offline/disconnect, está fora do $/ C Q$, tem outras formas, pode estar online e não querer ser perturbada". 
Quadro 1 - Indladores dos Processos de Deserwolvimento e Suas Definiçōes ${ }^{2}$

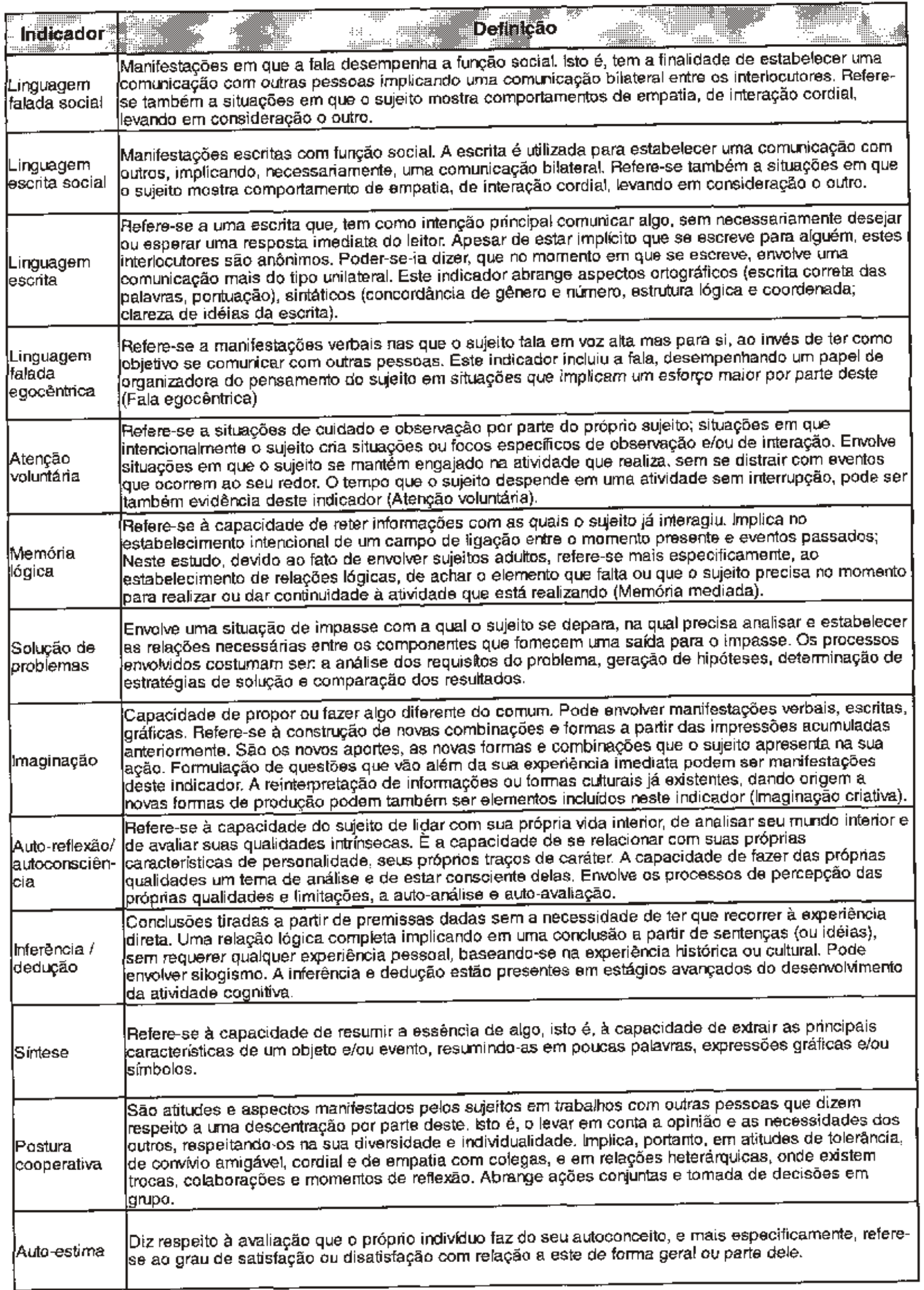


No Caso 2, este tipo de linguagem -processo psicológico superior rudimentar - também esteve presente ao longo de todo o processo de apropriaçāo, mediando a interaçăo do sujeito com outras pessoas. 0 sujeito 2 (S2) tambem o utilizou para solicitar auxiljo, perguntar, contar o que estava pensando realizar, contar seus planos de trabalho. A linguagem falada social foi usada pelo sujejto para compartilhar com a pescuisadora, obsevadora, facilitadores do NIEE e colegas PNEEs as infomaçóes novas que ia descobrindo com as suas buscas na web.

O sujeito expressou, através da fala, seus desejos, explicando melhor os seus propósitos, bem como contando eventos e aspectos ímportantes sobre sua vida. A atividade escrita de confeçăo de homepage $\theta$ criação de sua lenda (que ele chama de sua "obra prima") "), esteve impreghada da fala social, uma vez que o sujeito desejava escrever as palavras corretamente e as idéias de forma clara, por isso formulava perguntas sobre estes aspectos, nas inúmeras situaçŏes em que teve dúvidas.

Um fato importante a relatar é que o sujeito fez uso da fala social para dar início a seu processo criativo de escrita, pare "desianchar" pois, inicialmente, ditou a observadora o que "ia surgindo na sua mente", conforme ele mesmo justificou, se preocupando apenas com o fiuir das idéias e năo com os aspectos de grafia $\theta$ digitaçäo da tarefa. Posteriormente, a fala social servitu para que enquanto o sujeito realizava buscas na web e esperava o resultado destas buscas, falasse sobre si para os demais. Este aspecto, que pode passar despercebido em outras pessoas, toma-se relevante, uma vez que $\$ 2$ costuma ser timido, só passando a manifestar mais suas emopoojes com um longo tempo de convivio.

Através da fala social, pôde-se perceber a inquietação em procurar uma explicaçāo à sua condjção física ("de deffciente" como colocou em suas palavras), e uma procura de melhor conhecer-se ou seja, uma busca de sua "identidade". Nesta tentativa de busca, o sujeito recorreu a leituras e explicaçóes místicas, espirituais. Algurias das importantes evidèncias sobre a linguagem falada social incluiram situaçöes em que o sujeito soliçitava informaçöes noves e/ou auxilio sobre o funcionamento das femamentas informáticas que utilizava. A fala social foi observada também em situaçöes em que o $\mathrm{S} 2$ compartilhava ou manifestava emo६̧̆еs.

Tambem foi evidenciada quando o sujeito explicava seu raciocinio a outras pessoas e quando falava sobre si com outros.

\section{A Linguagem Escrita Social}

No caso 1, caracterizou-se no momento em que o sujeito levou em consideraçăo o leitor, o intertocutor das sua mensagens escritas, estabelecendo um certo diálogo com ele. Isto póde ser observado quando o sujeito começou a intercalar perguntas nos mails, dirigidas aos interlocutores, o que evidenciou uma mudança importante, uma vez que o sujeito a partir desse momento mostra-se preocupado em envolver seu interocutor. Pessou também a utilizar frases cordiais nos mails e a incluir frases de empatia.

Caracterizou-se também por haver servido para provocar alguma açāo no cutro, como quando o sujejto escreveu ao site interativo para reclamar que sua contribuição ainda não haviam sido acrescentada, reivindicando que o fizessem. A linguagem escrita social foi usada por $\mathrm{S1}$ para conhecer melhor os internautas que estava recém recém conhecendo, ou para retomar contato com visitantes do NIEE que, naquele momento, se comunicavarn à distancia.

Esta linguagem foi também usada pelo sujeito para falar sobre si mesmo, fazendo-se conhecer por pessoas que encontrava no ciberespaço, para compartilhar conhecimento ou para enșinar a outros. A linguagem escrita social foj ainda observada em situaçäo em que $\$ 1$ ofereceu ajuda ou apoio a amigos virtuais e quando comunicava e companilhava os sucessos obtidos.

Este tipo de linguagam social foi usado por $\$ 1$ para fazer brincadeiras com pessoas do Nucleo e para solucionar problemas. Por exemplo: escreveu mail de adivinhaçăo, colocando algumas dicas para que o bolsista de informática tentasse adivinhar quem era; via mail, pediu informaçāo ao tio que mora na Argentina sobre seu pais e pediu tamberm ajuda a um professor argentino, que a pesquisadora lhe disse conhecer; mandou mail oa encarregado de gerenciar o servidor do NIEE, evisando que terminara o dicicnário cooperativo e dizendo-lhe qual era o caminho que devia percorrer para localizar tal arquivo. 
Finalmente, foi através da linguagem escrita social que o sujeito interagiu, incentivando outros colegas nas comunicaçōes síncronas a participarem: "Tta legal o chapeú, falta a bruxa. Quem se habilita?" "fiz um desenho, quem colabora no quadro?"

A linguagem escrita com funçăo social, diferentemente da linguagem falada social e da linguagem escrita, nāo foi observada no caso 2 , uma vez que o sujeito näo se interessou em comunicari-se com outras pessoas, nem através de ferramentas de comunicaçáo síncrona como assincronas. Apesar dos recursos terem sido apresentados, o sujeito 2 năo os explorou, e esses acabaram sendo abandonados.

\section{Linguagem Eșcrita}

No caso 1 as pistas/evidencias sobre linguagem escrita foram muito frequentes e se encontram em diversas situaçōes. A linguagem escrita foi usada pelo sujeito 1 para sintetizar ou re-significar informaçōes novas que encon trava na web, durante navegaçóes realizadas. Por exemplo, após ler a jornal on-line, digitava seu próprio texto, incluindo algumas informaçōes novas que descobrira e reformulando outras. Serviu também para compartilhar o conhecimento adquirido - o sujeito elaborou textos sobre informática para um jornal colaborativo do grupo de PNEEs do NIEE ou quando dava instruçōes por chat sobre como proceder.

O desenvolvimento da linguagem escrita pôde ser observado na melhoria da grafia, da sintaxe e da estrutura lógica da escrita, como foi captada nas situaçöes a seguir: passou a escrever mails claros e objetivos, com pontuação correta e frases curtas; escreveu mail com uso correto de vírgulas, pontos, parènteses, dois pontos e letras maiúsculas; corrigiu seu texto, percebendo erro de concordância verbal; escreve mail longos e bem estruturados, contendo introduçăo meio e fim.

Em situaçôes de atividades escritas, podem ser observadas descobertas e outros aspectos, envolvendo a linguagem escrita em outros idiomas, por exemplo: escreveu mail em "portunhol" respondendo para amigas de escola mexicana, com quem se correspondia; ao ler mail de amigas se deu conta de que "os computadores" (las computadoraș) têm gênero feminino em espanhol; ao ser perguntado pela pesquisadora se tinha aprendido nowos termos em inglês, na realizaçăo da atividade Dicionário Colaborativo, respondeu via ICQ "off corse" (naturalmente).

No caso 2 a linguagem escrita, contrastando com a linguagem escrita social, esteve bastante presente ao longo das observaçōes. Acredita-se que o desejo de "ser escritar", como verbalizou o próprio sujejto, tenha otimizado o processo da leitura e da linguagem escrita.

Inicialmente, o processo de escrita se deu de uma forma mais passiva por parte do sujeito, que pedia para a pesquisadora anotar no caderno dele, conforme ia ditando sua história. Em tentativas que o sujeito havia realizado, solicitava constantemente que se the soletrassem muitas patavras. A etapa em que ele ditava (digitando mais tarde), parece haver sido de extrema importåncia as sujeito, por ele ser muito lento na digitaçāo $\theta$ no manuseio do equipamento em geral. Nesta situaçăo, em que se concentrava no aspecto imaginativo, a elaboraçāo/criaçăo da história ocorreu com uma velocidade que surpreendeu a pesquisadora, e outros facilitadores do Núcleo, pois parecia ter "revelado" urn potencial desconhecido no sujeito, que anteriormente escrevia apenas textos muito pequenos.

Ao longo do trabalho, percebeu-se uma melhoria nos aspectos de pontuaçăo e ortografia, pois o vocabulário rico, apropriado e preciso assim como o estilo da lenda foram detectados desde o infcio do "deslanchar" do prọesso de criaçāo.

O processo de autonomia na apropriaçăo da tinguagem escrita também é algo a ressaltar. O sujeito 2 , inicialmente, pedia que escrevessem para ele passando a copiar, como já foi aqui relatado. Depois passou a digitar e a criar diretamente, porem, perguntando constantemente ou olhando para a pesquisadora aparentando que buscava uma certa aprovaçăo de sua parte. Em seguida, passou a perguntar menos e a arriscar mais, perguntando somente algumas vezes. Em alguns momentos posteriores, quando em dủvida, a pesquisadora escrevia as hipóteses levantadas pelo sujeito quanto a grafia das palavras, na tentativa de ele mesmo descobrir a forma correta. Este procedimento pareceu ajudar o sujeito, uma vez que ao visualizar as palavras, optava, na maioria das vezes, pela forma correta.

O processo de apropriaçăo da linguagem escrita caracterizou-se por uma persistência do sujeito em escrever e revisar constantemente de forma que tivesse o menor número de erros. Constatou-se, por parte deste sujeito, o uso de um vocabulário rico, preciso, e estilo de escrita adequado ${ }^{4}$. 
E interessante notar na escrita de $\$ 2$, o uso de frases contendo analogias para methor expressar as características atribuídas por ele a sua personagem principal e um cuidado em utilizar os símbolos corretos de diálogos ("'s), perguntas (?). êntase (1) bern como usar títulos em maiúsculas, escolhendo como tipo de letra a Lucinda Blackletter, para dar a idéia de uma letra de época, que, segundo o sujeito combinava com o estilo de sua lenda.

Um outro aspecto sobre a linguagem eserita ocorreu em relaçăo à organizaçảo de textos longos, em capitulos ou hiperlinks. O sujeito, após organizar sua história em capítulos, os dividiu em documentos web que podem ser acessados desde o inicio da página ou a qualquer momento da leitura ou navegação, dando a impressão de que havia internalizado o conceito de hipertexto pois, a partir dessa primeira organizaçāo, passou a acrescentar novos capítulos, năo se preocupando tanto quanto à seqüéncia lógica linear de histórias impressas, como vinha realizando.

\section{Linguagem Falada Egocêntrica}

De modo geral, poucas foram as pistas/evidẻncias observadas que constatassem a presença da linguagem falada egocêntrica para ambos os sujeitos. No entanto, embora poucas, estas parecem haver sido muito importantes para resolução de situaçōes problemas. Para o caso 1 foram resgatadas as seguinteș: o sujeito testava novos icones da versão de software recém instalado, comparando-os e verbalizando a descoberta em voz alta para si: "a versão antiga tem. só tem. Este parece fazer o mesmo que antes"; Ficou em dúvida mas, falando err voz alta para si o que havia observado outros fazer, consegue lembrar de todo o processo de conversta de figuras, que anteriormente havia observado alguém realizar.

No caso 2, este tipo de linguagem apareceu principalmente no processo de apropriaçāo da leitura e da linguagem escrita, relacionada à grafia correta, que representava ao sujeito uma atividade bastante dificil, devido a seu nivel de escolarizaçäo ( 3 ' série de escola especial). Este desafio parece ter sido "vencido" com a ajuda da linguagem falada egocêntrica. No processo de apropriaçāo dos recursos computacionais, paralelamente à apropriaçắ da escrita, o sujeito 2 açeitou a sugestăo da observadora de que falasse mentalmente ou em voz alta, para si mesmo, contorme ia escrevendo. Este procedimento pareceu haver seguido uma ordem as palavras eram compostas letra por letra ${ }_{r}$ e depois silaba por sílaba e finalmente, o sujeito passou a escrever frases. Somente entăo, pessou a revisar a sua escrita.

\section{Memória Lógica}

Tal como a atençăo, parece ter sido uma das funçōes superiores mais presentes no processo de apropriaçáo em ambos os casas. No caso 1, esteve presente quando o sujeito 1 lembrava comandos ou procedimentos aprendidos. Ficou mais evidente quando eie mesmo ensinava a outros colegas, presencial ou virtualmente e quando S1 dernostrava lembrar URLs de sites e recor ria caminhos longos até localizar arquivos de que precisava, em rede interna.

A memória esteve presente em situaçóes em que o sujeito 1 devia configurar o seu browser, para ler ou enviar mails ou para interagir com outras ferramentas que precisavsm ser personalizadas para cada usuário". Nestes casos, o sujeito 1 realizava processos longos que exigiam a lembrança de intormaçóes sobre como usar esses sotware, muitas vezes, apesar desses nāo serem usados freqüentemente.

Este PPS ficava evidente também no momento em que o sujeito precisava verbalizar detalhadamente os procedimentos que deviam ser efetuados por outras pessoas, sem que ele mesmo manuseasse o equipamento e sem poder ativar os recursos sobre os quais desejava falar, o que apresentava uma maior dificuldade que quando se está no comando do computador. Explicou, por exemplo, à pesquisadora o seguinte procedimento (sem manusear o computador): "primeiro a gente fern que entrar no composer, clicar com o botăo direito na figura e o botão recortar e depois paste".

O sujeito 2, por sua vez, apresentou, inicialmente grande dificuldade em guardar informaçóes do ambiente computacional telemático. Em vista disso, ele precisava, ser constantemente questionado e estimulado a lembrar procedimentos já realizados e, mesmo assim, nem sempre conseguia lembrar. Não lembrava informaçōes fomecidas no mesmo encontro ou em encontros anteriores.

A memória, no entanto, apresentou mudanças muito significativas no decorrer do tempo. Passou a lembrar, por exemplo, URL's de sites de busca como o Altavista, Câde e outros e todos os passos para a busca 
na web, is to 6, o lugar onde a URL deve ser digitada, a delimitação do idioma das páginas, a colocaçāo de palavras-chave para busca e apertar o botão de início de busca.

Foram observadas situaçóes, ao longo do estudo, em que o sujeito precisou realizar procedimentos longos para localizar os arquivos em que desejava trabalhar ou outros procedimentos anteriormente realizados como, por exemplo, o salvamento de figuras da web e a sua inserçáo em homepages que construía.

\section{Atenção Voluntária}

Também bastante presente, podendo ser verificada em inümeras e variadas situaçöes da pesquisa. Apareceu tanto em momentos iniciais como em momentos no decorrer do estudo e próximos aco encerramento das observaçōes. No caso 1 foi evidenciada quando o sujeito observava outros colegas mais experientes interagirern, ouvia explicaçóes sobre novos recursos, experimentava ele mesmo os recursos sobre os quais já tinha alguma infomação prévia ou explorava aqueles que desconhecia por completo. Nesse contexto, quando apareciam mensagens de erros, o sujeito se concentrava para desvendá-los.

A atenção pôde ser obsevvada, no caso 1 , em atividades de comunicação sincrona e assíncrona, nas quais o sujeito participava quando respondia a perguntas, durante trabalhos cooperativos am que precisava seguir a seqüencia lógica destes trabalhos ou em outras operações que tentava realizar, mas näo obtinha sucesso, passando a empenhar esforços para verificar e entender o por quê do erro. Também pode sêr observada quando o sujeito utilizava versöes de software diferentes.

Outras situaçōes em que a atenção foi elemento importante foram aquelas em que o sujeito escrevia o seu diário, isto é, relatava sobre o que ele havia realizado na sessảo, bem como em momentos que mantinha a concentraçäo, apesar dos comentários err voz alta e de risos dos colegas ao seu redor.

Pode-se dizer que a atençăo também foi inerente ao processo de revisão e correção dos erros de sua própria escrita e de outros com quem interagia, fosse via chat, mail ou trabalhos realizados em outros software. Este processo psicológico superior foi facilmente percebido quando o aluno trabalhava durante longos periodos na mesma atividade, sem parar, enquanto o sujeito lia os mails e respondia a eles, principalmente, àqueles em inglèss ou em espanhol, e, finaimente, nas situaçōes em que verificava a ocorrência de problemas em trabalhos cooperativos sincronos e na atividade de resoluçăo dos mesmos, em que se engajava por iniciativa própria.

No caso 2, a atençāo tàmbém póde ser observada ao longo de todo o estudo, quando o aluno escutava interessado has explicaçōes e demonstraçōes sobre como funcionam os diversos software, hardware e outros elementos que constituem o ambiente computacional telemático, como foi o caso das ferramentas de busca na web. De forma sirnilar ao outro sujeito de pesquisa, no sujeito 2 , a atenção esteve também presente em situaçes am que testava, ele mesmo, os novos comandos e quando observava outros interagindo com as ferramentas que the despertavam interesse.

A leitura interessada de informaçōes que encontrava na web, para selecionar aquela que considerava pertinente a seus propósitos e que enwolviam dados, figuras, fundos ou idéias novas para seus projetos, toi outra evidéncia de atençăo. Esta leitura era, muitas vezes, realizada em voz alta, e o deslocamento era acompanhado por seu dedo na tela, o que parecia facilitar a ação.

Da mesma forma, as correçōes de matérias de sua autoria envolviam atenção pois, nestas situaçōes, o sujeito tazia uma releitura do que ele havia realizado, percebendo incorreçöes ou realizando complementaçöes. o longo tempo que o sujeito dedicava às atividades foi evidéncia clara da presença de atençä́o no proçesso de apropriação, assim como também seu engajamento nas atividades em que não se desconcentrava, apesar dos eventos que ocorriam ao seu redor.

Outros comportamentos de atençăo observados no processo de apropriaçăo foram: a năo interrupçăo das tarefas para fazer intevalo ou lanchar, o que pode ser interpretado como interesse e atençăo; o empenho a dedicação na realizaçăo da atividade de escrita de sua lenda e de outros textos; a organizaçāo dos textos em hipertextos e a procura e seleçăo de figuras para passar a idéia que ele, como autor, desejava.

\section{Solução de Problemas}

Inúmeras foram as situaçōes em que foi evidenciada a função de solucionar problemas, no cașo 1.

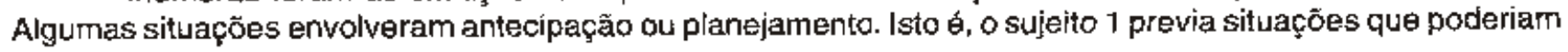


ocorrer e se antecipava a elas, corrigindo-as. Este foi o caso quando estava exercendo o papel de facilitador de uma jovem com sindrome de Down e solicitou ao bolsista de informática, antes de a sessão iniciar, que configurasse o Netscape para sua aluna, pois caso ela quisesse utilizé-1o, entraria com facilidade. Outra pista de antecipaçăo refere-se ao uso de dois recursos de comunicaçăo síncrona para se manter interligado aos colegas virtuais com quem realizava trabalho cooperativo on-line, caso um desses recursos falhasse.

Outras situações verificadas ocorreram em situação em que o sujeito não conseguia resolver problemas de lentidão ou congelamento do computador. Após fechar todas as outras janelas abertas de software, que é o procedimento indicado para aumentar a velocidade de processamento do computador, acabava reiniciando o o processo (desligando tudo), como última alternativa.

Ainda foi possivel observar soluçāo de probleña quando o aluno, realizando pesquisa sobre a Argentina para participar de um projeto colaborativo sobre cidades e paises, por năo conseguir todas as informaçōes que considerava necessárlas, enviou mail para diversas pessoas que moram naquele país, solicitando ajuda. Outra situaçāo problema que o sujeito resolveu foi quando não sabendo como proceder no uso avançado de ferramentas mais complexas, procurou o aux[lio de outras pessoas, fisicamente distantes, mas que tinham major dominio de informática, escrevendo mails ou mensagens, via $i C Q$, recebendo, assim: o auxílio esperado.

Em situaçães de chat com muitos usuários, em que era difícil entender o que os interlocutores falavam devido tanto à falta de sincronia quanto à identificaçäo confusa dos interlocutroes, $\$ 1$ sugeriu que todos se identificassem, colocando nāo os nomes dos computadores que utilizavam, mas os nomes dos usuärios. Finalmente, 0 uso de abreviações em comunicação escrita de palavras bastante usadas como "que ( $q$ ), você (vc), para (p) e cade vocé (codvc)" representou uma soluçăo encontrada para compensar o ritrno lento de digitação e ganhar mais tempo nesta atividade.

No caso 2, situaçōes em que a soluçãc de problemas esteve presente envolveram, principalmente situaçöes de navegaçäo, de busca de informaçōes na wob em que o aluno, interessado en determinado material, testava palavras de busca que poderiam the trezer material especifico, Isto implicava escolher pelavras que especificassem adequadamente o conteüdo desejado, ao invés de usar palavras aleatórias ou muito gerais, as quais costumam trazer vasto material, nem sempre contendo o procurado. Estas situaçōes se repetiram ao longo do estudo, uma vez que o sujeito se interessou preponderantemente a acessar novas informaçōes e a confecionar páginas wab.

Na construção de páginas wẹb, surgiram outras questōes que podem ser consideradas situaçōes problemas, nas quais o sujeito precisou buscar uma saída, como se pode observar na seqüência: Pronuncia em voz alta, letra por letra, depois as sílabas e palavras escritas; Devido à lentidão da rede em determinado dia, solicita se pode pesquisar ao mesmo tempo em outro computador, para maior aproveitamento do tempo, passando a realizar duas buscas simultãneas (um em cada máquina); Percebe que as letras que elabora não estão muito visiveis na página web, passando a selecionar todo o texto e testar diversas cores (laranja, branca, verde) até encontrar uma que apareça melhor na tela.

Foram constatados, tambérn para o sujeito 2, situaçoes de soluçăo de problemas por antecipação, como por exemplo a sua iniciativa de se auto-enviar paginas interessantes que encontra na navegação pois, no encontro anterior, foi necessario reinstalar Netscape, perdendo, com isso, as URL's que havia guardado nas bookmarks.

\section{Imaginaçāo}

A escrita diferento da comum que o sujeito 1 realizou apesar de saber como escrever corretamente, foi uma observação neste sentido: "Estou con saudades MIIIIIIIILLLLLLLI", para enfatizar sentimento; ao escrever seu nome, no final de mail. ao invés de escrever com $\mathrm{C}$ usa a letra $\mathrm{K}$.

Propostas de projetos novos ou assuntos pera serem desenvolvidos pelo grupo de PNEEs, do Núcleo, que o sujeito 1 fazia, foram manifestaçöes de imaginaçāo. Ela tambem esteve implícita nas matérias escritas como, por exemplo, na confeção de tabela no Excel, a qual era feita a comparaçăo dos horários no Brasil $\theta$ na Australia, atividade que realizou para cumprir tareta de gincana sobre Olimpiadas e a forma original como usou o mail para iniciar uma brincadeira que envolvia um bolsista de pesquisa, isto é, usou o mail da pesquisadora para evitar que o bolsista descubrisse facilmente quem havia the enviado a mensagem. 
A presença de imaginaçäo no processo de apropriaçăo, pode ainda ser vista quando o sujeito 1 cria um hino para o time de futebol da UFAGS ao qual seu irmão pertence e o envia via mail.

No cașo 2, a imaginaçăo, da mesma forma que a linguagem escrita e a linguagem falada social, aparece com bastante intensidade e freqüência. As atividades para as quais o sujeito canalizou sua oxploraçăo dos recursos do ambiente computacional telemático, propiciaram a manifestaçáo deste processo psicológico superior. Considerando que é na criação de páginas web, isto é. a publicaçăo de material eletronico na Internet, uma das principais atividades do sujeito 2, a maioria das pistas e evidéncias de imaginaçáo ocorreu neste contexto.

O sujeito não reproduzia ou copiava a informação encontrada durante as navegaçōes, mas se apropriava dela, adaptando-a incorporando-a na sua lenda de tal forma que era difícil para uma pessoa leiga no assunto, distinguir quais passagens correspondiam à mitologia grega e quais haviam sido criadas por ele. Além do enredo da história, a imaginação era visivel na criação de emblemas, logotipos, personagens e lemas. A imaginação também esteve presente na elaboração do layout visual das páginas que envolveu fundos, figuras, tipos, cores e tamanhos de letra. Os titulos tambérn envolveram inaginaçăo. Os seguintes exemplos podem ilustrar os aspectos aqui citados:

- Ao rever o triângulo que criou anteriormente, comenta que o circulo representa a reunião de Artemis; a estrela de cinco pontas, no centro do círculo se refere- aos cinco sentidos e no meio da estrela fica a pedra Ônix. Nas laterais desse triângulo estáo escritas as palavras: coragem (na base), proteçăo (na direita) e obediência (na esquerda);

- Continua a ditar a sua história, incorporando a simbologia recém criada:.." Para desviar ônix de seu propósito Artemis assume a fisionomia de Cristal para revelar-lhe que sel paj, Apolo, pediu para Hefesto confeccionar uma arma baseada na verdade, no conhecimento e no Dom de profecia, e que esta arma estaria em Delfos. Esta arma seria dada a quem demonstrasse coragem, obediência $\mathrm{e}$ tivesse a proteção dos deuses. Artemis revela, também, que Ónix terá que fazer uma jornada pelo mundo en busca da sabedoria. Ao ouvir estas palavras, Ónix reconhece Artemis e, por ser esta uma deusa, ela sente que está dianté da verdade absolufa sobre seu passado e só the resta aceitar o seu legado. Entāo, ela partiu transformada em uma ave que chamou de Talon";

- Deduçāofnterência - As pistas/evidéncias a seguir ilustram a constatação deste processo psicologico superior, no processo de apropriaçāo dos recursos tecrológicos presentes no caso 1: A correta descoberta que o sujeito $1 \mathrm{fez}$ da URL de site de emissora de rádio e de outros sites, seguindo a estrutura de iniciar com "www" __... com.br, baseando-se no conhecimento de outros sites que visitou; As semelhanças e diferenças encontradas a verbalizadas pelo sujeito entre o espanhol e o portuguess - " $y$ " com " $\mathrm{e}$ ", "fin" com "fim", enquanto lia mails de amigas estrangeiras; Deduçäo/fnferência tambèm estiveram presentes em todas as situaçōes em que o sujeito $\uparrow$ encontrave lcones correspondentes em versoes novas as quais estavam localizadas nos mesmos lugares que os icones usados para as mesmas funçōes, só que em versōes mais antigas.

No caso 2 as situaçōes de deduçăo/inferência não foram muitas. Algumas delas, no entanto, merecem destaque. A partir de uma informaçáco nova que o sujeito encontrou na web sobre mitologia: referente ao grau de parentesco entre personagens mitológicos e as personagens criadas por ele e que interagem na sua lenda, faz uma pausa nas buscas para contar à pesquisadora sobre a descoberta da heroina Xena "ela é fiha do irmão de Hercules, portanto é uma semideusa", diz. Na tentativa de atribuir ou definir em que animais a personagerm principal de sua lenda șe transformaria, procurou mais informaçōes, através da web, ao colocar come palavra de busca "felinos", estabeleceu a seguinte relaçáo: ao ler a intormaçāo encontrada de que os felinos dormem durante o dia e ficarn acordados à noite, comentou "isto significa que de acordo com esse costume os pode. res das amas felinas de Ônix só poderäo ser vilizados a noite".

Numa outra situação nova em que the foi solicitado para logarse no computador, isto é, que colocasse seu username e sua senha, deduziu que esta mensagem se referia à senha de mail que possula, pois era a única situação na qual tinha visto estas palavras.

\section{Sintese}

Algurnas pistas encontradas, sugerindo o processo/capacidade de sintese, foram as palavras que o sujeito 1 escrevia no campo "subject", ert todos seus mails, que resumiam o conteúdo do mail; também houve evidência desse indicador quando o sujeito lia matérias na web e, a partir delas, fazia seu próprio resumo. 
Alguns destes subjects, relacionados aos assuntos abordados nos e-mails, săo: adivinhação (enviando mensagem anỏnima de brincadeira a um bolsista); pesquisa (solicitando dados a sua pesquisa sobre a Argentina); homepage (avisando a amigos que sua homepage já estava no ar); amigo (desejando se corresponder com um novo amigo virtual); e-mail (solicitando a um colega surdo do Núcleo, que o ajudasse a entender uma mensagem que recebera $\theta$ que nāo entendera, de uma joven surda, de outra cidade); dicionário (avisando que a versão do dicionário colaborativo já estava pronto); tp (solicitando permissão para ter senha e realizar mudanças difetas no servidor, via FTP).

A capacidade de sintetizar no caso 2 manifestou-se, preponderantemente, na criação de emblemas, logotipos e lemas. A criação dos títulos dos capítulos e de outras páginas web foram tambèm manifestaçöes deste PPS. Em nivel de ilustração cabe mencionar, por exemplo, que o sujeito ao rever o triảngulo que havia criado, comentou que o círculo representava a reuniăo de Artemis (uma das personagens por ele criada); a estrela de cinco pontas no centro do circulo representava os cinco sentidos (olfato, visäo, tato, paladar e audiçăo) e, no meio da estrela a pedra ónix que significa força. Nas laterais desse triângulo havia escrito as palavras: coragem (na base), proteção (na direita) e obediência (na esquerda). Outro exemplo é quando o sujeito 2 solicita a pesquisadora que desenhe para ele, na mesma folha da história, dois triangulos: no primeiro inserese um circulo e dentro deste cfrculo uma estrela que representa o Clã das pedras das estrelas; no segundo triảngulo, também o círculo, mas que envolve uma lua minguante que representará alguma coisa a ser definida mais tarde.

\section{Autoconsciência/Auto-reflexão}

Lembrando que este PPS refere-se à capacidade da pessoa de entrar em contato com sua vida interior, com suas caracteristicas $\theta$ limitaçōes e de fazer destas tema de anàise, evidenciaram-se inumeras pistas evidências que os sujeitos tinham consciência de possuir, No caso 1, elas se referem a sua limitação motora, a sua característica de perseverança, a seu bom entrosamento com o novo grupo de colegas do NIEE, a sua necessidade de tempo de descanso após haver sofrido crise convulsiva, a seu conhecimento de ingläs năo ser suficiente como para responder mails nessa língua, a precisar de mais conhecimentos sobre homepages antes de iniciar a sua, que necessita estudar mais para näo ser reprovado novamente na escola, que se "atrapatha" com as novas versöes de novos programas que experimenta, que está frustrado devido à dificuldade de conexão dos colegas virtuais com quem trabalha e do quanto o computadior tem the auxiliado na escola. Numa outra situaçăo, reconheceu sentir-se sobrecarregado com todas as solicitações que o grupo com que trabalhava fazia a ele.

Em situação em que o sujeito 1 desempenhou o papel de facilitador de uma jovem com Sindrome de Down, ele percebeu $\theta$ comentou que estava indo rajpido demais por já ester há mais tempo no Núcleo, passando a regular melhor o ritmo. Comentou também estar sendo difficil explicar para a aluna e após uma sessão manifestou: "Hoje deu para cansar, é diffich explicar para ela".

Uma outra situaçáo interessante de auto-reflexão, que cabe ser ressaltada, fol a atividade de escrita de diários. Essa toi sugerida no final do estudo, em trabalhos cooperativos on-line con colegas virtuais de outros municípios, nos quais o sujeito 1 registrava por escrito o que considerava mais reievante e que geralmente envolvia o que tinha realizado, aprendido e entrentado durante as sessc̈es.

No caso 2, as situaçc̄es de autoconsciència/auto-feflexão foram variadas. Algumas ocorreram quando - sujeito havegava por sjites e obtinha informaçōes místicas e esotéricas, o sujeito se posicionava em relação às caracteristicas encontradas que se referiam a sua pessoe. Por exemplo, comenta: "paciente eu sou, inteligente também"; sobre sua caracteristica de curiosidade e de busca de conhecimentos novos, do que ele chama de "vida interior", comentou: "Meu lado positivo é, digamos, minha busca".

No que se refere à sua evoluçăo, desde que chegou ao NIEE, mostrou à pesquisadora um texto realizado em casa, que colocou na sua homepage intitulado "Minha Evoluçäo", na qual efetua a seguinte auto avaliaçāo: "Quando eu comecei a lidar com o computador, minha escrita não saia direito, mas como tempo fui me aprimorando. Assin, como eu melhorei a minha forma de escrever, meus fextos ficaram mais compressiveis. Que resultou-me fazer uma pesquisa sobre as guerreiras amazonas. Foi dessa pesquisa que criei a minha própria historia, à qual dei o nome de A Libertadora. ... Vou the dizer o porque deste nome, porque A Libertadora libertou a minha mente. E com o tempo eu mesmo fui aprendendo muita coisa com ela. Eu aprendi com ela que näo há nada a perder se nāo tutar. Deve-se tratar tudo como treinamento para um teste maior". 
A auto-reflexāo/auto-consciência toi evidenciada en $\$ 2$ em relaçāo a seu maior aproveitamento do seu potencial motor (utilizaçáo de ambas as mäos ao invés de apenas a esquerda) e também em relaçăo ao fato dele ter projetado elementos de sua vida, de sua pessoa, na personagem principal da lenda que escrevia.

Outros momentos em que o processo de auto-reflexão/auto-consciência aparece foram provocados intencionalmente pela pesquisadora. Nestes casos o sujeito responde à pergunta "como eras quando chegaste aquil", da seguinte forma: "Eu era um sonhador. mas (hoje) me vejo mais ativo, minha maneira de compreensăo, eu tenho maneiras de falar com o computador". A resposta à pergunta "o que achas que te estimulou mais aqui?"(no NIEE) foi: "A Internet me ajudou na minha instruçāo, eu me instrui através dela... minha professora está me educando atraves de maneiras de livros, e eu estou mais atualizado, ela diz para mim procurar em livros e eu tenho uma pagina para navegar".

\section{Auto-Estima/ Auto-Confiança}

A auto-estima, como jả foi definida no Quadro 1, refere-se ao grau de satisfaçào que a pessoa tern de si. A apropriaçāo crescente dos diversos recursos no ambiente de aprendizagem computacional telemático, por parte dos sujeitos, parece haver dado a eles um senso positivo em relaçăo a sua auto-estima/auto-confiança. Este aspecto pode ser percebido em varias situaçōes, em suas falas, atitudes, comportamentos e comuricaçós escritas. O sujeito 1, por exemplo, respondia mails de amigos virtuais, se colocando como "rrais experiente" e capaz de ajudá-los.

Outras interaçōes, envolvendo diretamente a pesquisadora, também ilustram a auto-estima/auto-confiança deste sujeito, que relatava a ela ter sido capaz de ensinar aos outros colegas e colocando-se, inclusive, à disposiç̧̄o da pesquisadora para ensinar-the e para aprenderem juntos: "Ana (pesquisadora): Quinta quando tiveres aí, na semana $q$ vem, a genfe ve juntos o ftp e conversaremos mehor. Botarei a página no ar (se quiseres ver) eu te explico coisas e tu outras, assim aprenderemos mais coisas juntos".

Em chats, na interação com professores de outros estados, deixou transparecer um sentimento de se sentir a vontade com a tecnologia: "Topo qualquer coisa", aceitando o desafio de desenhar colaborativamente com outros, fisicamente distantes no quadro de comunicaçoses; "Trabalho com qualquer um..".

A experiencia que envolveu PNEEs mais experientes ensinando novos colegas que haviam ingressado ao NIEE, posiçăo nunca antes experimentada ao longo de sua vida, na qual, segundo sua mãe "viveu eternamente aprendendo e treinando sem ter a chance de ensinar nada a ningúm" parece ter tido um impacto positivo na auto-estima/auto-confiança do sujeito 1.

De modo similar o sujeito 2, conforme vai avançando no processo de apropriação dos recursos no ambiente computacional telemático, parece adquirir um sentimento de satisfaçăo com ele mesmo, com a sua capacidade crescente de realizar procedimentos que antes näo era capaz. Inúmeras pistas/evidéncias deste aspecto de auto-estima/autoconfiança, entendidas também camo valorizaçāo dos progressos alcançados, ilustram este processo. Várias referem-se à sua capacidade de saber procurar informaçöes na web. Outras evidèncias dizem respeito à sua capacidade de reter informaçöes e de criar.

\section{Postura Cooperativa}

A postura cooperativa apareceu no caso $t$ em situaçōes em que o sujeito mostrou preocupaçăo com as outras pessoas tanto em interaçōes presenciais como nas virtuais. Envolveu também, uma atitude de descentração por parte do sujeito. Isto é, o sujeito levava em consideraçāo o que os demais pensavarn, ra realizaçăo de tarefas em grupo, não impondo seu ponto de vista, como fazia no inicio do estudo. Inúmeras evidẻncias deste indicador ocorreram em interaçōes on-line, quando desenvolvia trabalhos em grupo com colegas virtuais. Por exemplo, em chat do Netmeeting, durante trabatho cooperativo, pareceu ter claro que todos devem decidir juntos: $\mathrm{Diz}$, "O que ve gostaria de tazer pra proxima tarela? Ela vai ser decidida em conjunto com outros".

Outras situações foram presenciais em que ajudou os colegas do Núcleo, dando suporte ao menos experientes, a outras pessoas da equipe do NIEE ou a visitantes. Alguns exemplos: disse a urr tolega "eu vou ajudar a Claúdia, fica ai cuidando do Netmeeting (acompanhando o que ocorre no chat), que eu já volto; So ofereceu para explicar como funciona o ICQ ao novo facilitador do Núcleo; 
Prontificou-se a explicar a professoras dos Núcleos de Tecnologia de outra cidade que visitam o NIEE, o que estavam fazendo;

As concições em que a postura cooperativa foi evidenciada no caso 2, contrastam com as das do outro sujeito deste estudo, uma vez que este sujeito participou menos com colegas PNEEs, em função do caminho de exploração des NTICs que acabou escolhendo. Em outras palavras, as atividades pelas quais este sujeito se interessou e nas quais se engajou, refletem sua individualidade que implicou erm situaçóes de trabalho individual para que pudesse, ele mesmo, interagir diretamente com os recursos tecnológicos, ao invés de deixar os outros colegas o fazerem por ele. Contudo, urra postura colaborativa pode ser observada quando o sujeito compartilhava com a pesquisadora, com a observadora e com outros facilitadores do núcleo, o material encontrado, chamando-os e mostrando-lhes detalhes.

No decorrer do estudo o sujeito, que é tímido, compartilha inclusive, assuntos mais pessoais, sonhos, sua busca de identidade por caminhos espiritualistas e misticos e seus anseios. Nessas interaçōes com outras pessoas presentes fisicamente no NIEE, foi percebida uma descentraçāo por parte de S2 quando, ao navegar por sites que talassem de si, propiciava, às outras pessoas, que tambem conhecessem as informaçбes referentes a eles, que constavam nos sites visitados. Compartilhar o conhecimento por ele adquirido de busca na web, foi outro comportamento de cooperação, conforme pode ser percebido a seguir: Sorrindo, contente, mos. trou à secretària do NIEE como ela podo pesquisar na internet (pois ela havia contado que está cursando disciplina sobre mitologia) - minimizou história da Ônix e entrou no site Altavista, dizendo que pode colocar palavras como "Zeus", " Hércules" ou qualquer outra.

Por outro lado, cabe lembrar que durante todo o estudo este sujeito colaborou com a pesquisadora, no sentido de que quando esta intervinha solicitando maiores explicaçóes sobre o que ele estava realizando, visando interpretar corretamente os dados coletados, $\$ 2$ explicava quantas vezes fosse necessário, pois nem sempre sua fala anasalda era compreendida.

\section{Discussāo dos Resultados e Algumas consideraçăes}

Em termos gerais, com relaçáo aos Processos Psicológicos Superiores evidenciados ao longo do processo de apropriação por parte dos sujejtos com Paralisia Cerebral que participaram deste estudo, cabe ressaltar alguns aspectos importantes. Entre eles, deve ser mencionada a importância da atenção da memória ao longo do processo de apropriaçāo. Vygotsky (1993, 1984) constatou que a atençăo constitui-se em uma das funçóes superiores mais importantes, e que sua presença pode definir, em muitos casos, o sucesso alcançado nas atividades em que os seres humanos estāo engajados. A memóna, por sua vez, diz o referido autor, também dá suporte às outras funçóes mentais superiores, uma vez que é através dela que o campo de açăo pode ser prolongado, entre o passado e o presente, auxiliando na projeção de açōes futuras. Neste estudo, por tratar-se de adultos, observou-se a memória caracterizada por um al to grau de logicidade e pelo uso de signos internos, às vezes confundindo-se com o que inicialmente (fase da imersäo) toi percebido como "raciocinio lógico", mas que passou a ser entendido (na fase do mergutho) como memória mediada ou memória lógica.

Por outro lado, cabe analisar, em consonáncia com Vygotsky (2000), as observaçōes sobre as atividades de leitura e da escrita, também processos psicológicos superiores. Estas atividades, diz o mencionado autor, devem fazer sentido para o aluno e năo estarem centradas no professor, como costuma ocorrer em situaçōes escolares. O sujeito deve estar interessado na leitura e na escrita, e estar envolvido em algo significativo para ele. Em tais condiçōes, a aquisiçăo ou aprimoramento da leitura e da escrita ocorrerá naturalmente, observava Vygotsky, o que parece ser o caso de ambos os sujejtos deste estudo no ambiente computacional telemático em que interagiram.

Vale ainda tecer algumas considerações quanto à relaçāo entre pensamento e linguagem; em relação à fala egoceentrica.No que se refere à relação entre pensamento e linguagem, uma das premissas é que a necessidade de comunicaçāo (primeira função da linguagem- função social) parece haver impulsionado, inicialmente na filogénese, o desenvolvimento da linguagem. Falando especificamente sobre a linguagem escrita, foi possivel observar que esta premissa se aplica também no novo contexto, no ambiente computacional telemático. A necessidade ou o desejo de comunicar idéias no ciberespaço que, como se disse anteriormente, envolve preponderantemente a forma escrita, parece haver impulsionado o desenvolvinento da linguagem escrita em ambos os casos em estudo, contudo, de forma mais evidente no caso 2, como aparece nos resultados. 
Com relação à constataçằ da fala egocentrica, que acompanha a atividade dos sujeitos da pesquisa, yista com clareza na atividade de leitura e de escrita no caso 2, para quem tais atividades representavam grande dificuldade. A fala egocéntrica esteve presente também no caso 1, quando o sujeito utilizava pela primeira vez uma versăo mais atualizada de um software para comunicaçăo síncrona. Através da fala egocêntrica. o sujeito do caşo 1 comparou as duas versoues, falando em voz alta e para si mesmo sobre os elementos que identificeva presentes na nova versảo e sobre os que al encontrava, mas eram novos e, por isso, desconhecia. Segundo Vygotsky (1984), a fala tem um papel específico na realizaçăo da atividade prática do sujeito. Ela é tăo importante em alguns casos que a atividade năo ocorre sem que ela esteja presente. Fala e açăo são ambas importantes para a soluçāo de problemas, para atingir um objetivo. Os estudos de Vygotsky constataram que a presença da fala egocêntrica aumenta em relação direta com a dificuldade do problema enfrentado pelo șjeito. A fala egocêntrica, desse mado, teria uma função pessoal figada ao pensamento, sendo utilizada como auxiliar na solução de problemas. Chegou-se à conclusão de que é a linguagem que toma os indivíduos capazes de solucionarem taretas dificeis, de planejarem uma solução antes de se engajarem em uma atividade impulsivamente. Ela serve ao sujeito para controlar seu comportamento.

A fala egocêntrica, segundo Gallimore e Tharp (1996), representa um estágio importante na transfere̊ncia do controle ou na assistência da pessoa mais experiente ao aprendiz, menos experiente, uma vez que a principal tunção do discurso autodirigido è a autodireção. Tal principio permanece válido pelo resto da vida, explicando o por quê de os individuos adultos falarem consigo mesmos, conscientemente, buscando um autoauxilio. Apesar dos estudos de Vygotsky destacarem a criança, Gallimore e Tharp (1996) entendert que os processos idénticos de auto-asssistência, na ZDP, podem ser vistos também operando na aprendizagem adulta. Levando-se em consideração estes aspectos sobre a fala egocêntrica no ambiente do estudo em questão, a presença desse parece sugerir que este contexto, apresenta, de fato, situaçōes desafiadoras para os sujeitos, que se mostram interessados em resolvê-las, deixando transparecer o estlmulo que estas representam para o raciocínio.

Acredita-se que estas reflexóes sejarn importantes, por abordarem aspectos novos que surgern no contexto do ambiente computacional telemático, exigindo um repensar das categorias criadas para análisẹs em ambientes sociais, preexistentes ás NTiCs, especificamente às redes telemáticas. Nesse sentido, nestes novo cenário, as caracteristiças atribuídas a fala (como PPS rudimentar) e à linguagem escrita (como PPS avançado) aparecerth combinadas nas "interaçöes virtuais" - novo tipo de interaçăo social. Estas interaçōes costumam ocorrer de forma escrita, mantendo as caracteristicas no que se refere a um número maior de instrumentos de mediação. Contudo, estas interaçōes virtuais, também apresentam outros elementos tradicionalmente atribuidos à fala, no que diz respeito à agilidade com que as trocas entre os interlocutores ocorre.

Por outro lado, as funçōes superiores como a imaginaçäo criativa, a capacidade de solucionar problemas $e$ a autoconsciência/auto-refiexāo, que segundo Luria (1990) estariam entre as funç̧̄es mentais mais complexas, apareceram inumeras vezes e em diversas situaçóes do estudo, conforme foi relatado. A autoconsciência, afirma o referido autor, $\theta$ um dos processos psicológicos superiores mais difficeis de serem alcançados, pois é mais fácil refletir sobre o meio extemo (processo inten) do que sobre si (processo intra), seguindo o mesmo caminho de desenvolvimento que a Teoria Socio-histórica propōe. Quanto ao desenvolvimento dos sujeitos, constatou-se também outros aspectos importantes, na dimensāo sócio-afetiva, considerados neste trabalho, como processos de desenvolvimento. Foram eles, mais especificamente, a autorestima e a postura cooperativa. Acredita-se que ambas têm relevancia quando se consideram as especificidades do estudo.

A auto-estima, sentimento de satisłaçăo com relação a si mesmos e a seu desempenho na interação com $\mathrm{D}$ ambiente, por exemplo, è um elemento importante no desenvolvimento de qualquer pessoa, porém ela toma urna importảncia ainda maior quando se trata de seres humanos socialmente marginalizados que, multas vezes, já internalizaram o conceito pejorativo de "deficientes", "menos capazes", que a sociedade tem deles. Um crescimento na auto-estima para estas pessoas, sigrifica, portanto, um elemento importante, que, poderá impulsionar ainda mais o seu crescimento em outras áreas. Isto è, a descoberta por parte dos sujeitos do estrudo quanto a seu potencial auxiliou-os a se perceberem como capazes nāo so de utilizar com destreza as novas tecnologias de informação e comunicação mas também de contiruarem a aprender e a se desenvolverem pelo resto da suas vidas. A descoberta desse potencial parece haver favorecido que os sujeitos deste estudo nāo se acomodassem à situaçāo que até entāo vivenciavam, mas que procurassem novos caminhos, estabelecessem novas metaș, vencessem novos desafios, caminhasserm rumo a uma maior inclusāo social. 
A postura cooperafiva, por sua vez, envolve trocas entre pessoas. Ela abrange, no nosso contexto, a possibilidade de qualquer individuo aprender com os outros sem ser rotulado de "deficiente". Implica também na possibilidade das pessoas poderem ensinar outros (como pessoa mais experiente em alguma área), avançando, assim, rumo a um convivio mais heterárquico e de maior respeito. Com relaçáo à ela, mais evidenciada pelo caso 1 , pode-se destacar que houve um processo de descentração, de respeito pela diversidade e individualidade dos colegas, de atitudes de tolerância e de convívio cordial e de empatia com outros, de colaboraçōes e de tomadas de decisōes ern grupo e de forma consensual. A postura conperativa é importante no contexto deste estudo, por ser, cada vez majs, um elemento nocessário na época atuat em que vivemos, e que apresenta problemas complexos cuja solução requer a junçăo de esforços; é também importante dentro do contexto de globalização, no qual se faz necesstifio o resgate de aspectos humanizadores da educaçáo.

Oestudo mostrou também que, no processo de apropriaçao dos recursos do ambiente computacional telemático, os sujeitos desenvolveram habilidades motoras, principalmente relacionadas aos dispositivos de entrada - mouse e teclado - quanto à precisão, coordenação $\theta$ força que tais dispositivos requerem. For outro lado, parece ainda sugerir que, os sujeitos, ao se apropriarem das novas tecnologias de informação e comunicaçăo, vivenciram mudanças importantes no que diz respeito à percepção que a sociedade tem em relação a eles. Ao se apropriarem de tecnalogia de ponta, socialmente considerada complexa e sotisticada, os sujeitos da pesquisa passaram a ser percebidos com um status social mais elevado. Ainda cabe mencionar que foi observada ao longo do estudo uma dinämica de crescente autonomia por parte dos sujeitos, que fez com que a a intervençāo da pesquisadora como mediadora, se tornasse, aos poucos, menos necessária e portanto, menos freqüente.

Em suma, os resultados sugerem que, o ambiente de aprendizagem computacional telemático aqui proposto estimulou e ativou diversas funçöes mentais superiores, inclusive aquelas consideradas mais complexas. Em outras palavras, na medide em que os sujeitos interagiam com o ambiente, apropriando-se dos recursos, desenvolviam processos psicológicos superiores, habilidades motoras e aspectos sócio-afetivos.

Numa tentativa de conclusăo, ainda que temporariamente, uma vez que os nossos pontos de vista estäo sempre em constante evoluçăo, cabe refletir sobre o que Lévy já alertava em 1998 (Lévy, 1998) no que diz respeito às futuras geraçסes. O mais importante será a capacidade para gerir redes de comunicação e encontrar informaçōes com facilidade. Em outras palavras, a menté deveria ser preparada para a formalização e para regras de inferências. Estas seriam as evoluçðes que se estão esboçando na área educacional. Os resultados deste estudo mostraram, os sujeitos de pesquisa desenvolvendo precisamente esta capacidade de gerif redes de comuniçaçăo - no caso 1 -, de encontrar informaçōes na web - no caso 2-, e de estarem ambos mentalalmente agindo com situaçðes que exigem deles o raciocínio abștrato e, portanto, a formalizaçăo.

Finalmente, vale registrar aqui, o reconhecimento de que o tema em questăo está longe de ser esgotado. Espera-se, portanto, que muitas outras "imersōes" tantos outros "mergulhos" possam acontecer nessa complexa e fascinante integraçăo de duas realidades ainda bastante distantes - o mundo das pessoas com Paralisia Cerebral e o mundo da telemática".

\section{Notas do texto}

1 Pessoes com Necessidades Edwcachonals Especiaic.

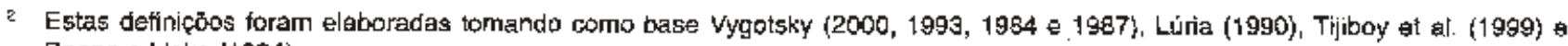
Beane e Llpka (1984)

a hittp.thwww.nlee.ufrgs.br/A_lende.him

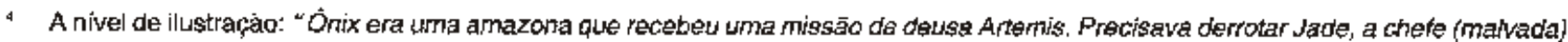

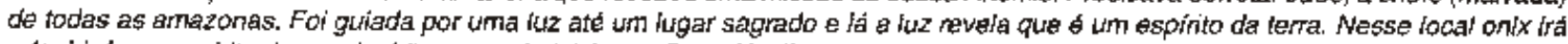

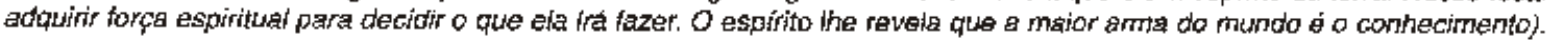

s Por exemplo, no mall, colocou romte, Lssername, em ail completo, se rvidor de salda, servidor de entrada, etc; configurou o Netmeeting

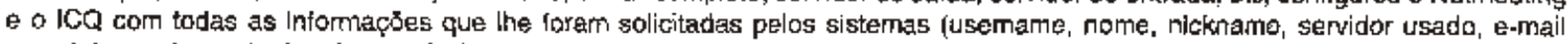
completo: sentha, pals de origern, nivel de segumang, etc)

4 Ao se encerrar a tese de doutorado, fomos infomatos de que os dois sijeitos da pesquisa continuaram o seu processo de desemai-

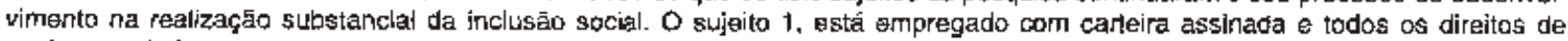
qualduer trabalhador "nomal", num escritónio, realizando atividedes de informática. O sujeito 2, freqüentemente e convidado a expor e comentar sobre sua experlancia do construça litaríria e artiatica com os resursos telemáticos. 


\section{Refferèncias bibliográficas}

ANDRADE, J. Site Defnet. Disponivel em http:/Www.defnet.org,br. Acesso em: 23 de abril de 2001.

BAQUERO, R. Vygotsky e a Aprendizagem Eseolar. Porto Alegre: Artes Médicas, 1998.

BASIL, C. Os Alunos com Paralisia Cerebral: desenvolwimento educaçăo. In: COLL, C.: PALACIOS, J.; MAPCHESI, A.; Desenvolvimento Peicológico e Educaçao: Necessidades Educativas Especiais e Aprendizagem Escolar. v. 3, Porto Alegre: Artes Mèdicas, 1995. p. 252-271.

BEANE, J.; LIPKA. R.; Self-concept, self esteeem and the Curriculum. New York: Teachers College Press, 1984.

CARMONA, M. a TORAES. M. Parálisis Cerebral: un nombre muly mal puesto. ATREVETE a ponerte en mí lugar. Santiado, Chile, ano 4, 10. 43, p. 15-19. diciembre, 1999.

DIXON-KRAUSS, L. Vygotsky in the Classroom: Mediated Literacy instruction and Assessment. New York: Longman, 1996 .

FIGUElRA, E. A tmagen do Portador de Deficiència Mental na Sociedacte e nos Mejios de Comunicaçăo. Integraçāo. Brasilia, ano 6, no. \$5, p. 31-34. MEC, 1995.

GALLIMORE, R. e THAPP, R. O Pensamento Educatiwo na Sociedade: Enșino, Escolarizaçảo e Discutso Escrito. In: MOLL. L. C. Vygotsky e a Educaçäo: Impliçaçóes Pedagógicas da Psicologia Sócio-Histórica. Porto Alegre: Artes Médicas, 1996. p. 171-199.

GHEZZO, R. Educação Inclusiva, Diferenças e Mudança Cultural. Porto Alegre, 12 de jultho de 19g9. Palestra promovida pelo Programa de Pós-Graduaçāo em Educaçäo da Faculdade de Educaçăo da Universidade Federal do Rio Grande do Sul e da Secretaria Municipal de Educaçáo. Professor do Centro di Documentazjone per L'integrazione AlAS - Projeto Calamaio, em Bologna, Itấlia.

LÉVY, P. A Máquina do Universo - criaçāo, cogniçāo e cultura informática. Porto Alegre: ARTMED, 1998.

LURIA, A R. Desenvolvimento Cognitivo - seus fundamentos culturais e sociais. Sảo Paulo: licone, 1990.

MiCHALAROS, J. A A troformatica na Comunicaçāo do Potador de Distúrbio neuromotor Grave. In: CAPOVILLA, F. C., GONÇALVES, M. J. Q MACEDO E. C. (org) Tecnologia em (Re)Habilitaçäo Cagnitiva: una perspectiva multidisciplinar EDUNISC: Sáp Paulo, 1998. p. 141-146.

NITSBET, P., et al. "Smart" Wheelchairs for Mobility Training. Technology and Disebllity, v. 5, 1996. p. 49-62.

OLWEIAA, M. K. Wygotokty - Aprendizado e Desenvalvlmento: um processo Sóció-Histórico. Sāo Paulo: Editora Scipione, 1997.

SOUZA, A M. COSTA de. Prognóstico Funcional da Paralisia Cerebral. In: SOUZA, A. M. COSTA DE; FEPFARETTO, L: (org.). Paralisia cerebral: aspectos práticos, Säo Paulo: Memnon, 1998, p.33-37.

SOUZA, A. M. COSTA DE; FERRARETTO, l.; (org.). Paralisia cerrebral: aspectos práticos, Săo Paulo: Memnon, 1998.

TIJBBOY. A. W. Aproprlaçăo das Tecnologias de Informaçáo e Comunlcaçăo no Desenvolvimento de Pessoas com Paralisia Cerebral. Tose (doutorado). Universidade Federal do Rio Grando do Sul, Programa de Pós-Graduaçăo em Informática na Educaçāo, Porto Alegre, 2001. 245 f.

TIJIBOY, A W. et al. Aprendizagem Cooperativa em Ambientes Telemáticos. Informática na Educaçäo: Teoria \& Prática. Revista do Curso de Pós-Graduaçào em Irformática na Educaça. ఛ. 2, n. 1, maio de 1999. p.19-28.

TINZMANN, M.B., et al. What is the Collaborative Classroom?. NCREL, [s.t.] Oak Brook, 1990.

VALENTE J. A. Creating a Computer-Based Learning Environment for Physically Handicapped ChIdren. 1983. Tese (Doutorado), Department of Mechanical Engineering of Massachusetts Institure of Technology, 1983. $206 \mathrm{p}$.

VYGOTSKY, L. S. A Formaçăo da Mente. Sáo Paulo; Martins Fontes, 1984.

VYGOTSKY, L. S. Pensamento e Linguagem. Săo Faulo: Marting Fontes, 1987.

YYGOTSKY, L. 5 . Obras Escogidas - II. Madrid: Visor, 1993.

WYGOTSKY, L. S. EI Desarrollo de los procesos psicológicos Superiores Barcelona: Crftica, 2000.

WERTSCH, J. V. Vygotsky y la Formaclón Social de la Mente. Barcelona: Paidós, 1995. 